\title{
Adaptive Water Law
}

\author{
Craig Anthony (Tony) Arnold*
}

\section{INTRODUCTION}

One of the most important questions concerning the governance of water resources in the U.S. is whether American water law regimes can become increasingly adaptive to changing conditions and sudden disturbances. Abundant evidence suggests that water law is non-adaptive or maladaptive. Many significant legal rules and processes governing water are static, rigid, and fragmented.

Three legal developments in the latter half of 2013 illustrate the kinds of maladaptive effects that water law can have. First, U.S. Bureau of Reclamation officials, environmentalists, and other stakeholders in the Colorado River have acknowledged that the Colorado River Compact's 1922 allocation of water quantities cannot be achieved under droughtdriven, dwindling flows and increasing demand, particularly from growing Nevada and Arizona communities. ${ }^{1} \quad$ An August 2013 Bureau operations plan identified a $50 \%$ chance that Nevada and Arizona will have their water deliveries cut by 2016 , in part because the Colorado River basin has suffered its two consecutively driest years in a century. ${ }^{2}$

More fundamentally, the Compact's allocation scheme is based on river flows that are mismatched to expected decreases in precipitation

* Boehl Chair in Property and Land Use, Associate Dean for Research and Faculty Development, Professor of Law, Affiliated Professor of Urban Planning, and Chair of the Center for Land Use and Environmental Responsibility, University of Louisville. Faculty Affiliate, Vincent and Elinor Ostrom Workshop in Political Theory and Policy Analysis, University of Indiana, Bloomington. I thank Jennifer-Grace Ewa and Alexandra Chase for excellent research assistance, and Lance Gunderson, Daniel DeCaro, and Barb Cosens for related research collaborations that informed this article. I also thank the presenters and participants in the Waters of the United States: Adapting Law for Degradation and Drought Symposium, hosted by the Kansas Law Review, November 1, 2013, for their helpful comments and feedback.

1. Anne MacKinnon, Slow Disaster: Dwindling Colorado River Will Demand Congressional Action, WyoFile.com (Aug. 20, 2013), http://wyofile.com/amack/slow-disaster-dwindlingcolorado-river-will-demand-congressional-action/; Ken Ritter \& Paul Foy, Feds Begin Colorado River Water Drought Measures, DENVER POST (Aug. 16, 2013), http://www.denverpost.com/ ci_23875051/feds-begin-colorado-river-water-drought-measures?IADID=Search-www.denverpost. com-www.denverpost.com.

2. Ritter \& Foy, supra note 1. 
and streamflows in the future. ${ }^{3}$ Likewise, the allocations are mismatched to actual demand for the water, particularly from the major metropolises of Denver, Las Vegas, Los Angeles, and Phoenix, all of which grew exponentially after the Compact was negotiated. ${ }^{4}$ Patricia Mulroy, former general manager of both the Southern Nevada Water Authority and the Las Vegas Valley Water District and one of the nation's most powerful managers of water, has responded by calling for a renegotiation of the Colorado River Compact, federal disaster aid, and a plan to pump 84,000 acre-feet of groundwater from rural, eastern Nevada to Las Vegas. ${ }^{5} \quad$ The groundwater pump-and-pipe plan hit a legal snag in December 2013 when a state judge ruled that the state water engineer needed to recalculate the project's environmental impacts and how those impacts would be mitigated. ${ }^{6}$ Mulroy retired in February 2014, which could leave a power vacuum. ${ }^{7}$

The existing rules governing water in the Colorado River Basin may shape or impede solutions, but they seem unlikely to create solutions to the basic problem of decreasing supply and increasing demand. While urban growth and inefficient water uses are clearly causes of the problem, ${ }^{8}$ simply cutting off the water supply to an existing urban population is not a politically or socially feasible option, regardless of how ill-conceived the location of Las Vegas is. Mulroy emphasizes that all basin stakeholders share in the risk that any of them face. 9 The once seemingly secure water allocations of the Colorado River Compact, the prior appropriation doctrine, and state groundwater laws are now of

3. MacKinnon, supra note 1 .

4. See id.

5. Sarah Goodyear, The Urban-Rural Water Wars of Nevada, NEXT CITY (Dec. 19, 2013), http://nextcity.org/infrastructure/entry/the-urban-rural-water-wars-of-nevada; MacKinnon, supra note 1 ; Ritter \& Foy, supra note 1.

6. Goodyear, supra note 5.

7. Editorial, Whatever it Takes to Bring Water to Valley, LAS VEGAS SuN (Feb. 17, 2014), http://www.lasvegassun.com/news/2014/feb/09/whatever-it-takes-bring-water-valley/. Mulroy's deputy and protégé, John Entsminger, was chosen to replace Mulroy as head of the two water agencies, but it remains to be seen whether he will exercise the power that she famously mustered. See id.; Conor Shine, Deputy Wins Water Authority's Approval to Succeed Mulroy, LAS VEGAS SUN (Jan. 16, 2014), http://www.lasvegassun.com/news/2014/jan/16/deputy-wins-water-authoritysapproval-mulroys-succ/.

8. See Robert Glennon, Unquenchable: America's Water Crisis and What to Do ABOUT IT 1-20 (2009).

9. Mulroy has made this point repeatedly. See, e.g., Patricia Mulroy, Beyond the Divisions: A Compact That Unites, 28 J. LAND RES. \& ENVTL. L. 105, 107 (2008); Patricia Mulroy, Climate Change and the Law of the River - A Southern Nevada Perspective, 14 Hastings W.-N.W. J. ENVTL. L. \& PoL'y 1603, 1609 (2008); Patricia Mulroy, Collaboration and the Colorado River Compact, 8 NEV. L.J. 890, 895 (2008). 
limited comfort to Las Vegas, the other Colorado River basin states and cities, and eastern Nevada farmers.

In a second example of maladaptive water law, Texas groundwater laws and property rights doctrines are hampering groundwater conservation districts' capacities to manage groundwater supplies sustainably, including the ability to deny pumping permits or require curtailment of pumping under conditions that threaten aquifers. The Texas Supreme Court has repeatedly held that the rule of capture governs groundwater rights in Texas, even though virtually every other state has overruled or abandoned this rule. ${ }^{10}$ The rule of capture recognizes the right of landowners overlying groundwater sources, such as aquifers, to exploit the resource by pumping as much as they want, which essentially incentivizes a race to extract more water faster than one's neighbors who also overlie the same groundwater source. ${ }^{11}$ Even though the Texas Legislature has created groundwater conservation districts to regulate groundwater pumping and conserve the shared resource, ${ }^{12}$ the Texas Supreme Court held that landowners own unpumped water under their land and can seek just compensation for takings if groundwater management districts restrict their pumping of that water. ${ }^{13}$

On November 13, 2013, a Texas appellate court handed down its decision in a takings case involving the Edwards Aquifer Authority's

10. Compare Houston \& T. C. Ry. Co. v. East, 81 S.W. 279 (Tex. 1904), and Sipriano v. Great Springs Water of Am., Inc., 1 S.W.3d 75 (Tex. 1999), with State v. Michels Pipeline Constr., Inc., 217 N.W.2d 339, 350 (Wis. 1974) (overruling the rule of capture).

11. Edward H. Rabin et al., Fundamentals of Modern Property Law 780 (6th ed. 2011).

12. Tex. WATER CODE ANN. §§ 36.001-36.419 (West 2013) (Chapter 36: Groundwater Conservation Districts). For the Edwards Aquifer Authority Act and its amendments, creating the Edwards Aquifer Authority, please see the PDF containing all relevant Act language at

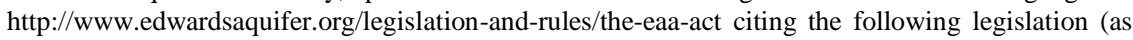
of September 1, 2013):

Act of May 30, 1993, 73rd Leg., R.S., ch. 626, 1993 Tex. Gen. Laws 2350; as amended by Act of May 16, 1995, 74th Leg., R.S., ch. 524, 1995 Tex. Gen. Laws 3280; Act of May 29, 1995, 74th Leg., R.S., ch. 261, 1995 Tex. Gen. Laws 2505; Act of May 6, 1999, 76th Leg., R.S., ch. 163, 1999 Tex. Gen. Laws 634; Act of May 25, 2001, 77th Leg., R.S., ch. 1192, 2001 Tex. Gen. Laws 2696; Act of May 28, 2001, 77th Leg., R.S., ch. 966, §§ 2.60-2.62 and 6.01-6.05, 2001 Tex. Gen. Laws 1991, 2021 and 2075; Act of June 1, 2003, 78th Leg., R.S., ch. 1112, § 6.01(4), 2003 Tex. Gen. Laws 3188, 3193; Act of May 23, 2007, 80th Leg., R.S., ch. 510, 2007 Tex. Gen. Laws 900; Act of May 28, 2007, 80th Leg., R.S., ch. 1351, §§ 2.01-2.12, 2007 Tex. Gen. Laws 4612, 4627; Act of May 28, 2007, 80th Leg., R.S., ch. 1430, §§ 12.01-12.12, 2007 Tex. Gen. Laws 5848, 5901; Act of May 21, 2009, 81st Leg., R.S., ch. 1080, 2009 Tex. Gen. Laws 2818; and Act of May 20, 2013, 83rd Leg., R.S., ch. 783, 2013 Tex. Gen. Laws

13. See Edwards Aquifer Auth. v. Day, 369 S.W.3d 814, 838 (Tex. 2012) (“[L]andowners do have a constitutionally compensable interest in groundwater ...."). 
restriction on the amount of water pecan farmers were permitted to pump from the aquifer. ${ }^{14}$ Even though the court acknowledged "the importance of [groundwater regulations to] protecting terrestrial and aquatic life, domestic and municipal water suppliers, the operation of existing industries, and the economic development of the state," it held that the Authority had taken the farmers' property and owed them just compensation. $^{15}$ The farmers bought their lands before the regulations were enacted, but then needed regulatory approval for the increased amounts of groundwater required by their now-mature pecan trees. ${ }^{16}$ The appellate court concluded that the farmers had a compensable property right to "the unlimited use of water to irrigate a commercial-grade pecan orchard." "17

The opinion ignores several key facts: the aquifer does not have unlimited amounts of water; those waters are shared by many overlying landowners who are in competition with one another to pump a limited resource; the aquifer provides most of the drinking water for San Antonio's large metropolitan population; the aquifer has to be maintained at certain levels to support species protected by the Endangered Species Act; and the aquifer's long-term viability has become increasingly threatened by overpumping and pollution. ${ }^{18} \mathrm{~A}$ property entitlement to pump an unlimited amount of water, secured against government regulation by the Takings Clause, is unsustainable and is illusory against changing conditions and the actions of other water users.

The mismatches between law and social-ecological conditions are not limited to the West, though. An example of problems facing eastern states appears in litigation over the U.S. Environmental Protection Agency's (EPA) failure to set quantitative nutrient standards for the Mississippi River Basin. ${ }^{19}$ Nutrient runoff, primarily nitrogen and

\footnotetext{
14. Edwards Aquifer Auth. v. Bragg, 421 S.W.3d 118, 123 (Tex. App. 2013).

15. Id. at 145,146 .

16. Id. at 124 .

17. Id. at 152 .

18. See generally Aquifer Guardians in Urban AReas, Protecting the Edwards AQUiFER: VulNERABILITY, CONTAMINATION, EFFECTS OF DEVElOPMENT, AND INADEQUACY OF ENGINEERED CONTROLS (2005), available at http://www.aquiferguardians.org/PDF/AGUAProtecting_Edwards_Aquifer.pdf; Edwards Aquifer Info, EDWARDS AQUIFER RESEARCH \& DATA CENTER, http://www.eardc.txstate.edu/about/aquifer-info.html (last visited Mar. 17, 2014).

19. See Gulf Restoration Network v. Jackson, No. 2:12-cv-00677, 2013 BL 253612, at *1-2 (E.D. La., Sept. 20, 2013), available at http://www.greatlakeslaw.org/files/gulf_restoration_network _ v_jackson.pdf (order granting in part and denying in part Gulf Restoration Network's motion for summary judgment urging the EPA to regulate nitrogen and phosphorous pollution in the
} 
phosphorus, is a major, persistent, water-quality problem in the U.S. ${ }^{20}$ Nutrient runoff from farms, cities, suburbs, and wastewater treatment facilities throughout the thirty-one-state Mississippi River Basin has caused a large hypoxic zone in the Gulf of Mexico, killing and preventing biological life in an area amounting to nearly 6,000 square miles. $^{21}$ A consortium of environmental groups filed a lawsuit against the EPA over its failure to set quantitative water quality standards for nutrients under the Clean Water Act. $^{22}$ In September 2013, a U.S. District Court judge in Louisiana ruled that the EPA was acting arbitrarily and capriciously by failing to decide whether to set quantitative nutrient standards or to develop Total Maximum Daily Loads (TMDLs) of nutrients for the entire Mississippi River Basin. ${ }^{23}$

The ruling, hailed as a victory by environmental groups, ${ }^{24}$ might ultimately lead to some increased actions to control nutrient runoff, but it is hardly a solution to a complex and far-reaching problem. The court only required the EPA to make a decision; it did not order the EPA to adopt quantitative standards, specify any particular quantities of impermissible nutrient levels, or require specific actions to reduce nutrient loading or runoff. ${ }^{25}$ The Clean Water Act continues to offer agricultural producers a substantial degree of protection from regulation of their nonpoint source runoff, including nutrient runoff from farms and ranches. ${ }^{26}$ The agricultural sector of the U.S. economy has strong influence over laws and policy solutions to environmental problems involving agricultural producers. ${ }^{27}$ Any establishment of TMDLs for nutrients in particular waterways and subsequent state actions to prevent

Mississippi River Basin).

20. Victor B. Flatt, Spare the Rod and Spoil the Law: Why the Clean Water Act Has Never Grown Up, 55 ALA. L. REV. 595, 597-99 (2004); J.B. Ruhl, Farms, Their Environmental Harms, and Environmental Law, 27 ECOLOGY L.Q. 263, 284-85 (2000).

21. See J. B. Ruhl \& James Salzman, Climate Change, Dead Zones, and Massive Problems in the Administrative State: A Guide for Whittling Away, 98 CAL. L. REV. 59, 60 (2010); Mississippi River Gulf of Mexico Watershed Nutrient Task Force, Northern Gulf of Mexico Hypoxic Zone, WATER.EPA.Gov, http://water.epa.gov/type/watersheds/named/msbasin/zone.cfm (last visited Mar. 17, 2014).

22. Mississippi River Collaborative, Dead Zone Decision: EPA Must Act on Mississippi River Pollution, MSRIVERCOLLAB.ORG (Sept. 23, 2013), http://www.msrivercollab.org/news.

23. Gulf Restoration Network, 2013 BL 253612, at *5-9.

24. See, e.g., Mississippi River Collaborative, supra note 22.

25. Gulf Restoration Network, 2013 BL 253612.

26. See Mary Jane Angelo \& James F. Choate, Agriculture and the Clean Water Act, in Food, AGRICULTURE AND ENVIRONMENTAL LAW (2013); Ruhl, supra note 20, at 296-305.

27. See Mary Jane Angelo \& James F. Choate, Agriculture and the Clean Water Act, in FoOD, AGRICULTURE AND ENVIRONMENTAL LAW (2013); Ruhl, supra note 20, at 296-305. 
violations of those TMDLs from throughout the relevant watershed will likely be slow and only partially effective at best. ${ }^{28}$ Litigation to force states to set and comply with TMDLs takes time and resources, and does not automatically create authority to regulate land uses, prohibit farmers or residential landowners from applying fertilizers to their lands, force landowners to manage waste from pets or livestock (or even wildlife, such as in the case of deer overpopulation), conserve critical lands, or restrict private property rights. ${ }^{29}$

Moreover, today's regulations may be ill-suited to tomorrow's problems. In particular, water quality standards and TMDLs are based on average conditions and sources of pollutants at a fixed point in time. ${ }^{30}$ Thus, they are not particularly flexible to peaks and valleys in stormwater runoff and streamflows, which may become more extreme as climate patterns change. ${ }^{31}$ They also address only one narrow aspect of a set of interconnected water problems. There are no guarantees that compliance with water quality standards for one set of pollutants will be coordinated with compliance standards for other pollutants or with solutions addressing other problems affecting the waterway. These other problems might include drought and reduced streamflows, flooding and high levels and velocities of runoff, impacts on aquatic and terrestrial species and their habitats, loss or degradation of wetlands, land-use and development patterns (e.g., sprawl), water consumption, impacts on fishing and fisheries, and many others. ${ }^{32}$ Litigation and regulation to set and enforce TMDLs for specific water pollutants play important, needed roles in protecting and governing water resources, but they are piecemeal tools that address only fragments of larger, interconnected water problems affecting both nature and society.

28. For criticisms of the TMDL program, see generally U.S. Gov'T ACCOUNTABILITY OFFICE, GAO-14-80, Clean Water ACt: CHANGES NeEded If Key EPA Program Is to Help FulfiLl THE NATION's WATER QUALITY GOALS 41-44 (2013), available at http://www.gao.gov/assets/660/ 659496.pdf; Oliver A. Houck, The Clean Water ACt TMDL Program: Law, Policy, AND IMPLEMENTATION (2d ed. 2002); James May, The Aftermath of TMDL Litigation: Consent Decrees and Settlement Agreements, ClEAN WATER ACT: LAW AND REgulation (2005), available at http://ssrn.com/abstract=1475422.

29. See supra sources in the preceding footnote.

30. See generally HoucK, supra note 28.

31. For the effects of climate change on flows, water quality, and other characteristics of watersheds, see infra the sources cited in note 45.

32. For a discussion of various aspects of water, land, and the environment that need to be comanaged with water quality or particular pollutants, see CRAIG ANTHONY (TONY) ARNOLD ET AL., KentUCKy Wet Growth ToOls For Sustainable DeVelopment: A HaNdBoOK ON LAND USE AND WATER FOR KENTUCKY COMMUNITIES (2009), available at http://louisville.edu/landuse /healthy-watersheds-land-use-initiative.html. 
These examples illustrate three maladaptive elements of water law: a reliance on law for a false security against change, rigid rules that impede adaptation, and a fragmented structure that fails to address interconnected water problems and decisions. This article argues that in order for society, communities, water governance institutions, and aquatic ecosystems to be resilient to stresses and disturbances from interconnected social-ecological change, water law will need to become increasingly adaptive. To do so, it will need to shift towards mechanisms for sharing risk, conditional and flexible standards, and integrated water governance structures. This article applies a relatively new framework of "adaptive law" to water law in order to identify several features of an adaptive water law system. Moreover, the evolution towards adaptive water law is already underway: while some aspects of water law remain maladaptive, the emergence and evolution of watershed governance institutions have infused some risk-sharing, conditional and flexible standards, and integrated water governance into water law. Watersheds are areas of land that drain to a common body of water, and are the ecosystem units at which hydrology and land-water-environment processes and functions occur, making them appropriate and useful scales for water governance and problem solving. ${ }^{33}$ The article uses case studies from several different kinds of watersheds to explore how adaptation for social-ecological resilience can develop in watershed governance. The article concludes with the observation that watershed governance institutions are not panaceas and encounter many obstacles to adaptive water governance, yet they offer great promise for improving the adaptive capacity of water law in the U.S.

\section{WATER LAW AND SOCIAL-ECOLOGICAL RESILIENCE}

\section{A. The Adaptive Capacity Imperative}

Water law must become more adaptive to changing social and ecological conditions. The static, rigid, and fragmented features of water law systems are not merely contributing to dried-up streams, shrinking aquifers, polluted waterways, flooded communities, imperiled species, and feuding water users. These features are also putting our communities and social-ecological systems at heightened risk of decline and collapse. Society's capacity to respond to disturbances and

33. Craig Anthony (Tony) Arnold, Adaptive Watershed Planning and Climate Change, 5 ENVTL. \& ENERGY L. \& POL'Y J. 417, 422-31 (2010). 
uncertainties is critical to navigating the dynamics of linked social and environmental systems, and water law plays an important role in either impeding or facilitating this adaptation.

Social systems and ecosystems, such as watersheds, are interlinked with one another in complex and dynamic ways, creating cross-system effects in which changes or behaviors in one system create disturbances in other systems. ${ }^{34}$ These disturbances might produce changes in other systems that are remote in time and space (i.e., nonlinear), including cascades of change, systemic collapse, and transition (sometimes known as systemic "flipping") to an alternate state. ${ }^{35}$ According to resilience science, systems can exist in multiple stable states and disturbances (sometimes called "perturbations") can trigger rapid change from one system to another, particularly if a system has lost resilience. ${ }^{36}$ Resilience is the capacity of a system to adapt to disturbances without losing its essential functions and structure. ${ }^{37}$

Society's "business as usual" consumptive patterns and practicesincluding building major cities in deserts or floodplains, water-intensive farming or land-development practices, damming and other reengineering of natural water systems, and using waters as sinks and drains for pollutants and polluted runoff — can cause the decline and substantial transformation of aquatic ecosystems. ${ }^{38}$ Moreover, a broad range of disturbances in our social systems - including economic decline and public fiscal crises, political gridlock among Congress and presidential administrations, changes in population makeup and locations, and judicial decisions reinterpreting the scope of the Clean Water Act or other water laws - can significantly affect water resources and aquatic systems. ${ }^{39}$ Ecological changes — such as prolonged drought, high-intensity floods, the proliferation of invasive species, changes in climate patterns, and others-can substantially impact human

34. See generally PANARChY: UNDERSTANDING TRANSFORMATIONS IN HUMAN AND NATURAL SYSTEMS (Lance H. Gunderson \& C. S. Holling eds., 2002).

35. See generally DisContinUities In ECOSYSTEMS AND OtHER COMPLEX SyStems (Craig R. Allen \& C. S. Holling eds., 2008).

36. Craig R. Allen et al., Commentary on Part One Articles, in Foundations of ECOlOGiCAL RESILIENCE 3, 6 (Lance H. Gunderson et al. eds., 2009).

37. Brian Walker \& David Salt, Resilience Thinking: Sustaining Ecosystems and PEOPLE IN A CHANGING WORLD xiii (2006).

38. See GLENNON, supra note 8; id. at 2-3, 15-27, 39-52, 96-110; Lance H. Gunderson et al., Water RATs (Resilience, Adaptability, and Transformability) in Lake and Wetland Social-Ecological Systems, 11(1) ECOLOGY \& SOC'Y 16 (2006).

39. Craig Anthony (Tony) Arnold \& Lance H. Gunderson, Adaptive Law and Resilience, 43 ENVTL. L. REP. 10426, 10429, 10431, 10439-40 (2013). 
communities, economies, public policies, and even laws. ${ }^{40}$

Perhaps, most significantly, societal actions can reduce the resilience of ecosystems, which in turn reduces the resilience of society and social systems. ${ }^{41}$ One prominent example was the Dust Bowl: unsustainable agricultural policies and farming practices, when combined with substantial and prolonged drought, produced dust storms that stripped away the topsoil, killed and hurt people, harmed the farmland ecology of the southern Great Plains, and irreparably changed communities and people's lives. ${ }^{42}$ Another prominent example was Hurricane Katrina's impacts on New Orleans: our resource management policies substantially reduced coastal plain wetlands, placed vulnerable urban populations in low-lying areas, and relied on human-engineered systems to hold back storm surge, all of which changed the fundamental capacity of southern Louisiana's natural systems to absorb storm surge from a major hurricane, which in turn led to major flooding, loss of life and property, the collapse of civil society during the disaster, the lack of effective governance capacity during the disaster, and a fundamental change to the structure and functions of the New Orleans community. ${ }^{43}$ In the case of Katrina, the feedback loops from society to nature to society and back to nature because the damage may contribute to more climate change. A study in Science used empirical data and extrapolation to predict that dying vegetation from Hurricanes Katrina and Rita may release an amount of carbon equivalent to $50 \%$ to $140 \%$ of all the carbon that forests in the U.S. absorb from photosynthesis in an entire year. ${ }^{44}$

40. Id. at 10427-28; Robin Kundis Craig, Adapting Water Law to Public Necessity: Reframing Climate Change Adaptation as Emergency Response and Preparedness, 11 VT. J. ENVTL. L. 709 (2010); Holly Doremus \& Michael Hanemann, The Challenges of Dynamic Water Management in the American West, 26 UCLA J. ENVTL. L. \& POL'Y 55, 57-62 (2007).

41. See PANARChy, supra note 34.

42. See Timothy Egan, The Worst Hard Time: The Untold Story of Those Who Survived the Great American Dustbowl (2006); Donald Worster, Dust Bowl: The SOUTHERN PLAINS IN THE 1930s (1979).

43. See Ctr. for Progressive Reform, Pub. No. 512, An Unnatural Disaster: The AFTERMATH OF HURRICANE KATRINA 10-23 (2005), available at http://www.progressivereform. org/articles/Unnatural_Disaster_512.pdf; R. W. Kates et al., Reconstruction of New Orleans After Hurricane Katrina: A Research Perspective, 103 PROC. NAT'L ACAD. SCI. 14653 (2006); Colin D. Woodroffe et al., Landscape Variability and the Response of Asian Megadeltas to Environmental Change, in Global Change and Integrated Coastal Management: The Asia-Pacific REGION 277, 308 (Nick Harvey ed., 2006). For the social and distributive justice implications of Katrina, see MANUEl PASTOR ET AL., In THE WAKE OF THE STORM: ENVIRONMENT, DisASTER, AND RACE AFTER KATRINA (2006), available at http://katrinareader.org/sites/katrinareader.org/files/wake _of_the_storm.pdf.

44. Jeffrey Q. Chambers et al., Hurricane Katrina's Carbon Footprint on U.S. Gulf Coast Forests, 318 SCI. 1107, 1107 (2007). 
Indeed, an example of social-ecological dynamics that many communities are facing today is climate change. Society's practices that emit greenhouse gases into the atmosphere are changing climate conditions and patterns, which in turn are affecting water resources and producing prolonged and severe drought, high-intensity floods, more extreme storm events, hotter temperatures that increase consumptive demand for water, changes in evaporation and evapotranspiration rates, more polluted runoff during high-intensity storms, and other similar changes. ${ }^{45}$

Moreover, the future is uncertain, at least partially and in significant ways. Past conditions are poor predictors of future conditions, especially with respect to water. Both scientists and legal scholars have declared that "stationarity is dead." 46 This phrase means that emerging water conditions, fluctuations, and trends have no precedent in recent history. ${ }^{47}$ Therefore, water laws, policies, and management decisions that are based on assumptions that aquatic conditions fluctuate within a fixed range defined by data from past conditions (i.e., "stationarity") no longer match actual or future conditions. ${ }^{48}$ In many cases, we do not have reliably certain models to predict conditions at the relevant geographic scale or time scale that we need for making decisions. For example, climate change models about impacts on water systems globally or regionally over decades do not simply "scale down" to models that predict climate change impacts on particular local watersheds or on annual water flows and supplies. ${ }^{49}$ Moreover, we often cannot predict precisely when and

45. See generally NAT'L SCI. \& TeCH. CounCIL, SCIENTIFIC AsSESSMENT OF THE EFFECTS OF Global Change on the United StATES 12-13 (2008), available at http://downloads.global change.gov/ccsp/CCSP_Scientific_Assessment_Full.pdf; JOEL B. SMITH, PEW CENTER ON GLOBAL Climate Change, A Synthesis of Potential Climate Change Impacts on the U.S. iv-v, 1112 (2004), available at http://www.c2es.org/docUploads/Pew-Synthesis.pdf; U.S. GLOBAL CHANGE Research Program, Global Climate Change Impacts in the United States 41-42 (2009), available at http://downloads.globalchange.gov/usimpacts/pdfs/climate-impacts-report.pdf; Kathleen A. Miller, Grappling with Uncertainty: Water Planning and Policy in a Changing Climate, 5 ENVTL. \& ENERGY L. \& POL'Y J. 395 (2010).

46. Robin Kundis Craig, "Stationarity Is Dead"-Long Live Transformation: Five Principles for Climate Change Adaptation Law, 34 HARv. EnVtL. L. Rev. 9 (2010); P.C.D. Milly et al., Stationarity is Dead: Whither Water Management, 319 SCI. 573 (2008).

47. Milly et al., supra note 46 , at 573 .

48. Id.

49. See texas Water Development Board, Far West Texas Climate Change CONFEREnCE: Study Findings And Conference ProceEdings 1, 16-17 (2008), available at http://www.twdb.state.tx.us/publications/reports/special_legislative_reports/doc/climatechange.pdf; Lara C. Whitely Binder, Climate Change and Watershed Planning in Washington State, 42 J. AM. WATER RES. ASS'N 915, 924-25 (2006). 
where an ecological system or social system will reach a tipping point that creates crisis, sudden decline, or rapid transformation to a different state or regime. ${ }^{50}$ For example, resilience science suggests that the impacts of land-development and population-growth dynamics on water supply capacity or the quality of surface waters and groundwater (or a combination of water supplies and quality) are likely to contain surprise effects that we have not yet predicted accurately.

Humans and human organizations make significant mistakes when managing natural resources and implementing management decisions. This point is partly grounded in what resilience science tells us about the characteristics of linked social-ecological systems: complexity, nonlinear dynamics, feedbacks between systems that can amplify across scale and time, and surprise tipping points that produce unexpected regime changes. ${ }^{51}$ However, it is also grounded in limits to human cognitive capacity and the nature of organizational behavior. Humans have heuristic biases that affect cognitive processing and lead to mistakes in judgments and decisions. ${ }^{52}$ Comprehensive "rational" plans often fail due to inaccuracies in prediction of changing conditions and limits in organizational capacity to implement plans and make decisions according to rational cognitive processes. ${ }^{53}$ Organizational structures, mission biases, power allocations, and intra-organizational relationships and dynamics often impede rational decision making and accurate predictions about the effects of decisions. ${ }^{54}$ Scientific models and data may be ill-matched to or disconnected from governance structures, processes, and needs. ${ }^{55}$ The potential for enormous up-front mistakes from comprehensive, rational, front-end planning of natural resources management decisions, in particular, has led scientists and natural

50. DisCONTINUITIES IN ECOSYSTEMS, supra note 35.

51. See supra notes $34-40$ and accompanying text.

52. See James G. March, Decisions and ORganizations (1988); James G. MarCh \& Herbert A. Simon, ORganizations 203-10 (1958); Judgment Under UnCERTAinty: HEURISTICS AND BiASES (Daniel Kahneman et al. eds., 1982); Christine Jolls et al., A Behavioral Approach to Law and Economics, 50 STAN. L. REV. 1471, 1545 (1998).

53. See Charles E. Lindblom, The Science of “Muddling Through”, 19 Pub. Admin. Rev. 79 (1959) (discussing the difficulties in implementing rational public policies).

54. See MARCH, supra note 52; MARCH \& SIMON, supra note 52. For an assessment of the inherently change-resistant nature of water organizations, in particular, see Denise Lach et al., Maintaining the Status Quo: How institutional Norms and Practices Create Conservative Water Organizations, 83 TEX. L. REV. 2027 (2005).

55. See David Feldman \& Helen Ingram, Making Science Useful to Decision Makers: Climate Forecasts, Water Management, and Knowledge Networks, 1 Weather, Climate, \& SOC'Y 9, 10 (2009). 
resources managers to develop a model of adaptive management in which resources, such as waters and watersheds, are managed in a series of experiments with continual adjustment based on feedback loops of monitoring, assessment, and learning. ${ }^{56}$

Improving the adaptive capacity of water systems requires the use of adaptive management methods, ${ }^{57}$ as well as legal reforms to authorize or facilitate adaptive management. ${ }^{58}$ It also requires the use of adaptive planning methods and processes, particularly in the context of water supply planning, water-quality planning, and watershed planning. ${ }^{59}$ Furthermore, it requires the development of adaptive water governance systems. ${ }^{60}$ However, improving the adaptive capacity of water systems also requires adaptive features in the legal system itself, particularly water law.

\section{B. The Maladaptive Reality of Water Law}

Many features of water law in the U.S. lack the capacity to adapt to changes and disturbances. Moreover, these features inhibit society from adapting to changes and disturbances and contribute to reductions in the adaptive capacity of nature and its ecosystems. Three particular aspects of U.S. water law regimes deserve special attention. They are the attempt of water law to provide individuals and organizations with security against uncertainty and change, the rigidity of water law, and the fragmented nature of water law.

56. See Adaptive Environmental Assessment and Management (C. S. Holling ed., 1978); CARl Walters, Adaptive Management of Renewable Resources (1986); Bradley C. Karkkainen, Adaptive Ecosystem Management and Regulatory Penalty Defaults: Toward a Bounded Pragmatism, 87 MinN. L. REV. 943 (2003); Kai N. Lee \& Jody Lawrence, Adaptive Management: Learning from the Columbia River Basin Fish and Wildlife Program, 16 ENVTL. L. 431 (1986).

57. See Mary Jane Angelo, Stumbling Toward Success: A Story of Adaptive Law and Ecological Resilience, 87 NEB. L. REV. 950 (2009).

58. See Robin Kundis Craig \& J.B. Ruhl, Designing Administrative Law for Adaptive Management, 67 VAND. L. REV. 1 (2014).

59. See Arnold, supra note 33.

60. See AdAPTIVE GOVERnANCE AND WATER CONFLict: NEW InSTITUTIONS FOR Collaborative Planning (John T. Scholz \& Bruce Stiftel eds., 2005); Barbara A. Cosens \& Mark Kevin Williams, Resilience and Water Governance: Adaptive Governance in the Columbia River Basin, 17(4) ECOLOGY \& SOC'Y 3 (2012); Per Olsson et al., Shooting the Rapids: Navigating Transitions to Adaptive Governance of Social-Ecological Systems, 11(1) ECOLOGY \& SoC'Y 18 (2006). 


\section{False Security}

Water law often aims to provide its participants with lasting security in the allocation and protection of water supplies, conditions, and rights. It uses legal rules and processes to lock-in existing conditions and protects investments, expectations, and the institutional status quo by resisting change. This security is a false one, though.

In general, U.S. water law regimes favor the security of private rights to use water, which deter adjustments in water allocations and uses as new conditions demand. The prior appropriation doctrine guarantees a senior appropriator the right to continue to appropriate and use a specific quantity of water that the appropriator has historically put to a beneficial use at particular times and in particular locations, as well as the right to enforce its priority against junior appropriators when supplies are limited. ${ }^{61}$ This is true even if the senior appropriator is making a relatively low-value or inefficient use of the water, if sharing would maximize the net utility of the water source to society, or if hydrological conditions have changed, making it very costly to ensure that adequate flows or water pressure reach the senior appropriator. ${ }^{62}$ Moreover, in several takings cases, courts have awarded compensation to private water-rights holders for government-mandated reduction in their rights when environmental and supply conditions have changed. ${ }^{63}$ If government regulators adjust water rights to absorb changes or adapt to disturbances, they have to compensate the rights-holder as if the government is an insurer or guarantor against change. The judicial takings doctrine might even prohibit state courts from changing property laws, no matter how incrementally or expectedly in response to changing conditions, if they eliminate existing property interests. ${ }^{64}$

An alternative way for water law to adapt to changing conditions is through market transfers of water rights from lower-value uses to higher-

61. Janet C. Neuman, Adaptive Management: How Water Law Needs to Change, 31 ENVTL. L. REP. 11432, 11432 (2001).

62. Id.

63. See., e.g., Tulare Lake Water Storage Dist. v. United States, 49 Fed. Cl. 313, 324 (2001); Casitas Mun. Water Dist. v. United States, 543 F.3d 1276, 1296 (Fed. Cir. 2008); Edwards Aquifer Auth. v. Bragg, 421 S.W.3d 118, 152-53 (Tex. App. 2013).

64. Stop the Beach Renourishment, Inc. v. Fla. Dep't of Envtl. Prot., 560 U.S. 702, 724-25 (2010) (plurality opinion) (dictum); see Craig Anthony (Tony) Arnold, Legal Castles in the Sand: The Evolution of Property Law, Culture, and Ecology in Coastal Lands, 61 SYRACUSE L. Rev. 213, 219-24 (2011). 
value uses. ${ }^{65}$ However, market transfers often face obstacles in the form of no-injury rules protecting junior appropriators or area-of-origin protections for communities that depend on existing arrangements. ${ }^{66}$ The effects are ossification of existing allocations when they no longer make sense, and the systemic incapacity to change allocations through legal modifications to water rights or market-based transfers.

Government decisions also fix standards for future behavior on the basis of past conditions that may bear very little relationship to future conditions or needs. Interstate compacts persistently guarantee states specified allocations of interstate waters based on historic conditions that have changed. Current and projected conditions cannot possibly supply the sum of all interstate water allocations that have been guaranteed by law. ${ }^{67}$ Likewise, local water supply plans are all too often based on "paper rights" rather than "wet water"-actual reliable supplies for the foreseeable future. ${ }^{68}$ Government regulators typically set water quality standards, TMDLs, and the conditions of permits issued under the Clean Water Act based on conditions and projections at a given point in time and then do not revise those standards based on new circumstances. ${ }^{69}$ Likewise, land-use or development permits are meant to create certainty for landowners about how property may be used or developed, and it can be difficult to add or revise regulatory controls once a project is complete. $^{70}$ Thus, many new regulatory standards apply to new permit applications but do not require retrofitting or redevelopment of existing land uses.

In many respects, laws, rules, rights, and permits serve as insurance policies against change. The beneficiaries of these certainty-creating legal tools have few incentives - or at least perceive that they have few

65. Mark Squillace, Water Transfers for a Changing Climate, 53 NAT. RES. J. 55, 56-59 (2013).

66. Id. at 59-61; see also, e.g., N.C. GEN. STAT. ANN. § 143-215.22L (West 2013) (regulating surface water transfers); Christine A. Klein, Water Transfers: The Case Against Transbasin Diversions in the Eastern States, 25 UCLA J. ENVTL. L. \& POL'Y 249 (2006).

67. See Noah Hall, Interstate Water Compacts and Climate Change Adaptation, 5 EnvTL. \& ENERGY L. \& POL'Y J. 237, 321-322 (2010); MacKinnon, supra note 1.

68. See Susan D. Brienza, Wet Water vs. Paper Rights: Indian and Non-Indian Negotiated Settlements and Their Effects, 11 STAN. ENVTL. L.J. 151, 159-60 (1992); Lincoln L. Davies, Just a Big, "Hot Fuss"?: Assessing the Value of Connecting Suburban Sprawl, Land Use, and Water Rights Through Assured Supply Laws, 34 ECOLOGY L.Q. 1217, 1282 (2008); Doremus \& Hanemann, supra note 40, at 72.

69. See, e.g., U.S. Gov'T ACCOUNTABILITY OFFICE, supra note 28, at 41-44.

70. For a discussion of the demand for certainty, security, and clear rules in land use regulation, see Harvey M. Jacobs, Fighting Over Land: America's Legacy. .. America's Future?, 65 J. AM. PLANNING Ass'N 141 (1999). 
incentives - to proactively enhance their capacities to adapt to disturbances or change, voluntarily modify existing arrangements based on new conditions, or seek out other interested parties for the sharing of risks and adaptation strategies. These perceptions of legally guaranteed security deter interested parties from coming to the bargaining table to improve the adaptive capacity of water systems; yet the law cannot prevent disruptive physical, ecological, and social conditions from altering water systems. Rights-holders are discovering that their rights may mean little under unprecedented drought, flood, landscape alteration, or climate disruption. At best, the law will determine who pays and who gets paid when disturbances turn legal certainties into empirical uncertainties or impossibilities. The use of law essentially to subsidize private risk from social-ecological change imposes substantial systemic costs that undermine the resilience of the overall system.

\section{Rigid Rules}

Water law in the U.S. is full of inflexible rules that inhibit adaptive responses to disturbances and changes. One example is the prior appropriation system of water rights that governs water allocation in western states. Janet Neuman has summarized the rigidity of the doctrine:

The doctrine is considered a hard-edged, or "crystalline," set of rules, as opposed to the looser "muddy" riparian doctrine followed in more water-rich areas. In other words, where water is a scarce and precious resource, the legal system has evolved a set of fairly rigid rules for assigning rights to water use. The prior appropriation doctrine operates on a first-in-time, first-in-right principle, where the first person to put the water to beneficial use acquires the superior legal right, and junior water rights holders must relinquish water in times of shortage. In contrast, the riparian doctrine that pertains where water is more plentiful follows a share-and-share-alike principle where everyone (or at least each riparian) is entitled to a reasonable share of the water resource, and all users cut back on a pro rata basis in times of shortage.

Prior appropriation as a system of water allocation is thus rigid in a number of ways. The doctrine locks in and protects historical uses, many of which were established over a hundred years ago in the western United States, without regard to whether those uses embody current views on the "highest and best use" of limited water. Approximately $80 \%$ of the water use is in irrigated agriculture, in a region where natural precipitation ranges as low as a few inches. Shortages (which are frequent in arid regions) are handled on a strict priority basis, with the more junior water users being cut off. The 
doctrine does not reward efficiency; indeed efficiency improvements and conservation are often effectively penalized because any water not used for the prescribed statutory period of time is considered legally forfeited. The major goals of the system are predictability and certainty to support economic investment in consumptive uses of water. Even though water is scarce, water users know exactly where they stand in relation to each other, and users can predict on the basis of historical patterns how much water they will receive. Although attempts are being made to graft environmental demands for water onto the system, the graft has not fully taken, and water use in arid regions is still heavily tilted in favor of consumptive and economic uses such as irrigation, mining, hydropower, and municipal supply. Water rights are jealously defended as vested property rights against any alteration or interference. ${ }^{71}$

The rigidity of the priority system discourages or prevents adaptive sharing of water during shortages. The combination of measuring rights in specific quantities of appropriated water and the use-it-or-lose-it rule deter improved efficiencies and adaptive water conservation efforts. The persistence of defining beneficial uses by historic rules and uses prevents regulators or courts from determining that some water uses are no longer well-adapted to the conditions in which they occur.

Another type of rigidity in water law is the prevalence of either/or classifications. Water is either surface water or groundwater. It is either subject to the public trust or not. Pollution entering waterways is either from a point source or from a nonpoint source. Waterways and wetlands are either subject to complete federal jurisdiction or they are not subject to federal jurisdiction under the Clean Water Act (CWA). ${ }^{72}$ All water transfers between water bodies require a National Pollution Discharge Elimination System (NPDES) permit or none do under the "unitary waters" rule. ${ }^{73}$ If a situation is classified one way it is governed by a specific set of rules, but if it is classified the other way it is governed by a different set of rules. There are no hybrid classifications and no context-specific exercises of discretion to manage the situation adaptively. For example, transfers between water bodies might need some degree of regulatory oversight and assessment of potential impacts on water quality and system resilience without triggering the

\footnotetext{
71. Neuman, supra note 61, at 11432 (citing Carol M. Rose, Crystals and Mud in Property Law, 40 StAN. L. ReV. 577 (1988)).

72. Rapanos v. United States, 547 U.S. 715, 742 (2006).

73. See S. Fla. Water Mgmt. Dist. v. Miccosukee Tribe of Indians, 541 U.S. 95, 105-08 (2004); National Pollutant Discharge Elimination System (NPDES) Water Transfers Rule, 73 Fed. Reg. 33,697 (June 13, 2008) (codified at 40 C.F.R. pt. 122).
} 
cumbersome, bureaucratic, time-consuming process of obtaining a fullblown NPDES permit. Interconnected surface waters and groundwater would be more adaptively managed for social-ecological resilience in integrated legal and governance systems that avoid rigid classification systems. $^{74}$

Furthermore, federal environmental laws designed to protect aquatic environments are inflexible and lack sufficient adaptive capacity. For example, the Endangered Species Act (ESA) protects aquatic environments only if they are inhabited by federally listed endangered or threatened species. ${ }^{75}$ It does not prevent degradation of waterways that could lead to the decline of currently healthy populations or require proactive strategies to enhance the resilience of aquatic systems. The ESA prohibits modifications to habitats that are likely to harm species, but does not protect or manage the overall health and functioning of the watershed or waterway in which the species exists. ${ }^{76}$ Habitat conservation plans under the ESA - as well as environmental-impact reports for major federal water projects under the National Environmental Policy Act (NEPA) and TMDLs for impaired water bodies under the CWA-pre-commit agencies and regulated parties to actions and project features that may not be well-suited to future conditions, synergistic disturbances, or unexpected transitions from one ecosystem state to another. ${ }^{77}$ The front-end, prescriptive characteristic of federal environmental laws, including laws governing water resources, is maladaptive.

74. See Christina Hoffman \& Sandra Zellmer, Assessing Institutional Ability to Support Adaptive, Integrated Water Resources Management, 91 NEB. L. REV. 805 (2013).

75. See 16 U.S.C. $\S 1531$ (b) (2012).

76. See Tenn. Valley Auth. v. Hill, 437 U.S. 153 (1978); Holly Doremus, Water, Population Growth, and Endangered Species in the West, 72 U. CoLo. L. REV. 361 (2001); Todd H. Votteler, The Little Fish That Roared: The Endangered Species Act, Groundwater Law, and Private Property Rights Collide Over the Texas Edwards Aquifer, 28 ENVTL. L. 845 (1998). For an argument that the Endangered Species Act is static and rigid, unable to meet the needs of dynamic interconnected ecological and social systems, see Holly Doremus, The Endangered Species Act: Static Law Meets Dynamic World, 32 WASH. U. J. L. \& POL'Y 175 (2010).

77. U.S. Gov'T ACCOUNTABILITY OfFICE, supra note 28, at 41-44 (discussing TMDLs); Melinda Harms Benson \& Ahjond S. Garmestani, Embracing Panarchy, Building Resilience and Integrating Adaptive Management Through a Rebirth of the National Environmental Policy Act, 92 J. Envtl. Mgmt. 1420 (2011); Alejandro E. Camacho, Can Regulation Evolve?: Lessons from a Study in Maladaptive Management, 55 UCLA L. REV. 293 (2007) (discussing the failures of HCPs); Bradley C. Karkkainen, Toward a Smarter NEPA: Monitoring and Managing Government's Environmental Performance, 102 COLUM. L. REV. 903 (2002). 


\section{Fragmentation}

Water law is fragmented. ${ }^{78}$ Entirely different legal regimes-the riparian doctrine in eastern states and the prior appropriation doctrine in western states-govern rights to use surface waters, although some commentators observe that the two regimes have become increasingly similar. $^{79}$ In most states, the legal regime governing surface waters differs from the legal regime governing groundwater, and there is very little effective coordination between the two. ${ }^{80}$ The content of the public trust doctrine varies from state to state. ${ }^{81}$ A patchwork of difficult-tocoordinate federally-created legal interests in surface waters overlay onto state water rights doctrines. These interests include the federal navigation servitude, federal and Indian reserved water rights, legal regimes governing hydropower, and rules associated with development and management of water projects by the U.S. Bureau of Reclamation and the U.S. Army Corps of Engineers. ${ }^{82}$

Entirely different legal regimes protect water quality, even though laws governing surface waters contain some protections for instream flows, water conservation, and public interests in water. ${ }^{83}$ The primary legal tool for water-quality protection is the Clean Water Act. ${ }^{84}$ Despite a bold assertion of purpose - "to restore and maintain the chemical,

78. On the fragmentation of water law generally, see Christine A. Klein, On Integrity: Some Considerations for Water Law, 56 ALA. L. REV. 1009 (2005).

79. See, e.g., George William Sherk, Meetings of Waters: The Conceptual Confluence of Water Law in Eastern and Western States, 5 NAT. RES. \& ENV'T, 3-5, 47-49 (1991).

80. Klein, supra note 78, at 1059-64.

81. Robin Kundis Craig, A Comparative Guide to the Eastern Public Trust Doctrines: Classifications of States, Property Rights, and State Summaries, 16 PENN. ST. ENVTL. L. REV. 1, 4 (2007); Robin Kundis Craig, A Comparative Guide to the Western States' Public Trust Doctrines: Public Values, Private Rights, and the Evolution Toward an Ecological Public Trust, 37 ECOLOGY L.Q. 53, 56 (2010).

82. Barton H. Thompson, JR. ET Al., Legal CONTROL OF WATER ResourCes 604-12, 74659, 837-88, 1022-1134 (5th ed. 2013).

83. See Nat'l Audubon Soc'y v. Super. Ct., 658 P.2d 709 (Cal. 1983); Stempel v. Dep't of Water Res., 508 P.2d 166 (Wash. 1973) (finding that environmental impacts of proposed water diversion permit and fundamental state policy of an "ecological ethic" had to be considered in public welfare review of permit application); DAVID M. GILlILAN \& THOMAS C. BROWN, InSTREAM FLOW Protection: SEeking a BALANCE in Western WATER Use (1997); Washington DeP'T OF Ecology, Pub. No. 12-11-002, 2011 RePort to THE LEGiSlature: Statewide Progress on SetTING Instream Flows (2012); Christine A. Klein et al., Modernizing Water Law: The Example of Florida, 61 Fla. L. REV. 403 (2009); Joseph L. Sax, The Limits of Private Rights in Public Waters, 19 ENVTL. L. 473 (1988).

84. Federal Water Pollution Control Act, 33 U.S.C. $\$ \$ 1251-1387$ (2012). 
physical, and biological integrity of the Nation's waters" ${ }^{\prime 5}$ - the CWA has a fragmented structure. End-of-the-pipe discharges from industrial or wastewater systems, known as point source discharges, are subject to NPDES permit requirements and technology-based standards regarding the content of those discharges. ${ }^{86}$ Nonpoint source pollution-pollution from runoff - is subject to different kinds of regulation, though. Urban stormwater systems are point sources when they discharge into waterways and are regulated under the Municipal Separate Storm Sewer System (MS4) program, which requires NPDES permits. ${ }^{87}$ MS4 came about through congressional amendment of the CWA in $1987,{ }^{88}$ EPA adoption of Phase I regulations for large and medium stormwater systems in $1990,{ }^{89}$ and EPA adoption of Phase II regulations for small stormwater systems in 1999..$^{90}$ Municipalities subject to MS4 regulations and developers of sites one acre or larger must adopt "best management practices" (BMPs) to control runoff, ${ }^{91}$ but the CWA does not directly regulate the actual sources of runoff, such as urban and suburban homes or commercial landscapes.

Agricultural sources of runoff are mostly unregulated, except for Concentrated Animal Feeding Operations (CAFOs). ${ }^{92}$ Various programs under both the CWA and the Farm Bill aim to create financial incentives to encourage agricultural producers to reduce runoff or the pollutants in runoff. Moreover, states are required to establish water quality standards for surface waters and TMDLs for impaired waterways and then manage all sources of pollutants to comply with their TMDLs. ${ }^{93}$ But state laws and local ordinances, which are needed for states to reduce pollution, are often inadequate, ill-matched to the TMDL requirements, or lacking

85. Id. § 1251(a).

86. See id. $\$ 1342$.

87. See id. $\$ 1342(\mathrm{p})$.

88. Water Quality Act of 1987, Pub. L. No. 100-4, 101 Stat. 7 (codified as amended in sections of 33 U.S.C.).

89. National Pollutant Discharge Elimination System Permit Application Regulations for Storm Water Discharges, 55 Fed. Reg. 47990 (Nov. 16, 1990) (codified at 40 C.F.R. pts. 122-24).

90. National Pollutant Discharge Elimination System-Regulations for Revision of the Water Pollution Control Program Addressing Storm Water Discharges, 64 Fed. Reg. 68722 (Dec. 8, 1999) (codified at 40 C.F.R. pts. 9, 122-124).

91. Office of Water, EPA, Stormwater Phase II Final Rule: Who's Covered? DESIGNATION AND WAIVERS OF REgULATED SMALL MS4S 2 (2012), available at http://www.epa.gov/npdes/pubs/fact2-1.pdf.

92. See sources cited supra note 26.

93. See 33 U.S.C. $\$ 1313$ (2012). 
altogether. $^{94}$ Moreover, groundwater quality receives almost no protection under the CWA. Instead, it receives protection only from federal and state waste and hazardous-substances regulations, such as the Resource Conservation Recovery Act, ${ }^{95}$ the Comprehensive Environmental Response, Compensation, and Liability Act, ${ }^{96}$ and a variety of aquifer-specific state and local regulations. ${ }^{97}$

The development of wetlands is regulated jointly by the U.S. Army Corps of Engineers and the U.S. EPA under Section 404 of the Clean Water Act, but only to the extent that the wetlands have an adequate nexus to navigable waters. ${ }^{98}$ Wetlands that do not have an adequate nexus to navigable waters might receive some protections under state or local regulations, depending on where they are located. ${ }^{99}$ Aquatic habitat of fauna receives protections under the ESA but only to the extent that human activities will adversely affect the habitat on which federally listed endangered or threatened species live. ${ }^{100}$ The relationship between the ESA and water rights has been characterized more by conflict than by cooperative integration, ${ }^{101}$ and has produced several cases in which regulators owed compensation to water rights holders for taking their property interests. ${ }^{102}$ Moreover, the legal system may favor one law over another, instead of integrating the two. For example, the U.S. Supreme Court has held that the EPA did not have to consult with the U.S. Fish and Wildlife Service under the ESA when delegating water-quality permitting authority to the states under the CWA. ${ }^{103}$

One area that is particularly fragmented is the intersection among land use, water supply, and water quality. The relationships among these three aspects of the land-water interface are strongly interdependent and

\footnotetext{
94. See sources cited supra note 28.

95. Resource Conservation and Recovery Act, 42 U.S.C. $\$ \S 6901-6992$ (2012).

96. Comprehensive Environmental Response, Compensation, and Liability Act, 42 U.S.C. $\S \S$ 9601-9675 (2012).

97. See, e.g., supra note 12.

98. See 33 U.S.C. $\$ 1344$ (2012); Rapanos v. United States, 547 U.S. 715, 742 (2006).

99. Environmental Law Institute, State Wetland Protection: Status, Trends \& Model APPROACHeS (2008); Trevor B. Rockstad, Comment, The Three-Legged Stool: Ensuring Protection of Mississippi's Isolated Wetlands through Increased State and Local Regulation, 79 MisS. L. J. ONLINE 82 (2009). 100. 16 U.S.C. $§ 1531$ (b) (2012).

101. See, Holly Doremus \& A. Dan Tarlock, Water War in the Klamath Basin: Macho LAW, COMBAT BIOLOGY, AND DiRTY POLITICS (2008).

102. See., e.g., Casitas Mun. Water Dist. v. United States, 543 F.3d 1276 (Fed. Cir. 2008); Tulare Lake Water Storage Dist. v. United States, 49 Fed. Cl. 313 (2001).

103. Nat'l Ass'n of Home Builders v. Defenders of Wildlife, 551 U.S. 664, 673 (2007).
} 
intertwined, yet the legal system treats each as separate and distinct. Land use and development are largely matters of local government law; water supply is a matter of state water-rights laws as well as water organizations' planning and management authority; and water quality is mostly a matter of federal environmental law as delegated, at least partly, to state government. ${ }^{104} \mathrm{New}$ "wet growth" policies and legal tools at local and state levels of government aim to take a more integrated approach to the relationship between land use and water, but many localities have not embraced them or are using them incompletely or ineffectively. ${ }^{105}$ Moreover, flood management - a matter of federal flood insurance policies and disaster planning requirements, local and state hazard planning, federal agency management of waterways and water infrastructure, and local control (or non-control) of stormwater runoff and development locations - is another legally fragmented element of the hydrologically integrated land-water nexus. ${ }^{106}$ Climate change will make all of these land-water interconnections more important and even more complex and difficult to integrate with existing water law frameworks. ${ }^{107}$

At first glance, the fragmentation of water law might appear to be an

104. See generally Craig Anthony (Tony) Arnold, Fourth-Generation Environmental Law: Integrationist and Multimodal, 35 WM. \& MARY ENVTL. L. \& POL'Y REV. 771 (2011).

105. See ARnold et AL., supra note 32; Wet Growth: Should Water LaW Control Land UsE? (Craig Anthony (Tony) Arnold ed., 2005); Craig Anthony (Tony) Arnold, Is Wet Growth Smarter Than Smart Growth?: The Fragmentation and Integration of Land Use and Water, 35 ENVTL. L. REP. 10152 (2005); Lincoln L. Davies, Just a Big, "Hot Fuss"?: Assessing the Value of Connecting Suburban Sprawl, Land Use, and Water Rights Through Assured Supply Laws, 34 ECOlOGY L.Q. 1217 (2008); Dave Owen, Urbanization, Water Quality, and the Regulated Landscape, 82 U. Colo. L. REv. 431 (2011); Michelle Bryan Mudd, A Next, Big Step for the West: Using Model Legislation to Create Water-Climate Elements in Local Comprehensive Plans, 32 Wash. J. EnVT'L L. \& POL'Y 1 (2013); Michael Allan Wolf, Supreme Guidance for Wet Growth: Lessons from the High Court on the Powers and Responsibilities of Local Governments, 9 CHAP. L. REV. 233 (2006).

106. Donald Miller \& Gert de Roo, Urban Environmental Planning: Policies, INSTRUMENTS, AND METHODS IN AN INTERNATIONAL PERSPECTIVE 232 (2005) ("Planning for flood hazard in the United States . . is a fragmented patchwork of federal, state, and local authority."); Klein, supra note 78, at 1015-17; Christine M. McMill, Federal Flood Insurance Policy: Making Matters Worse, 44 Hous. L. REV. 471 (2007); Charles Todd Schartung, A Study of Severe Repetitive Loss Flooding: Identifying Costs, Risks, Vulnerable Populations, Community Values and Response through a Natural Hazards System Model (2010) (unpublished Ph.D. dissertation, University of Louisville) (on file with the author).

107. The energy-water nexus is also an area where improved integration is critically needed, given the physical and societal interconnections between these two sectors. See Ashlyn Stillwell et al., Energy-Water Nexus in Texas, 16(1) ECOLOGY \& SoC'Y 2 (2011); A. Dan Tarlock, Water Demand and Energy Production in a Time of Climate Change, 5 ENVTL. \& ENERGY L. \& POL'Y J. 325 (2010). 
adaptive feature. It is polycentric, and polycentrism is one of the core features of adaptive systems. ${ }^{108}$ Systemic resilience increases with both diversity of functions and responses to disturbance and modularity that compartmentalizes system features and therefore the effects of disturbances to those features (i.e., thus preventing the effects of extreme events or failures from spreading throughout the entire system). ${ }^{109}$ For example, if the TMDL system or Colorado's water courts system were to prove ineffective or even fail altogether, other laws and systems protecting water quality and allocating and managing water-use rights would continue to function.

Thus, water law's fragmented features are not maladaptive simply because they divide authority and create diverse, modular centers of action and power. They are maladaptive because they create governance scales and functions that are artificial, based on legal abstractions and political or administrative convenience, instead of organizing governance scales and functions around the scales and functions at which ecological systems and social systems intersect. ${ }^{110}$ The failure of environmental and natural resources law to use ecosystem scales of management and governance has long been criticized. ${ }^{111}$ Many experts in water management advocate for "Integrated Water Resource Management." Holly Doremus has argued that water management systems require the optimal degree of fragmentation that allows for variation, experimentation, and diffusion of risk and power, yet do not impede solutions to interconnected social-ecological problems at appropriate

108. See Elinor Ostrom, A Polycentric Approach for Coping with Climate Change (World Bank, Pol'y Res. Working Paper 5095, 2009), available at http://elibrary.worldbank.org/doi/pdf/10.1596/ 1813-9450-5095. For a discussion of mixed empirical results about polycentricity and adaptive governance systems, which focuses on how polycentrism relates to the legitimacy of governance systems, see Cosens \& Williams, supra note 60.

109. Stephen R. Carpenter et al., General Resilience to Cope with Extreme Events, 4 SUSTAINABILITY 3248, 3252 (2012). For an argument for modular environmental law, see Jody Freeman \& Daniel A. Farber, Modular Environmental Regulation, 54 DuKE L.J. 795 (2005).

110. Craig Anthony (Tony) Arnold, Clean-Water Land Use: Connecting Scale and Function, 23 PACE ENVTL. L. REV. 291 (2006).

111. See John M. Blair et al., Ecosystems as Functional Units in Nature, 14 NAT. RES. \& ENV'T 150 (2000); Bradley C. Karkkainen, Collaborative Ecosystem Governance: Scale, Complexity, and Dynamism, 21 VA. EnVTL. L.J. 189, 200-04 (2002); A. Dan Tarlock, Putting Rivers Back in the Landscape: The Revival of Watershed Management in the United States, 14 HaSTINGS W.-Nw. J. ENVTL. L. \& POL'Y 1059 (2008).

112. See, e.g., Am. WATer Res. Ass'N Policy Comm., Case Studies In InTEgrated Water RESOURCES MANAGEMENT: From LoCAL STEWARDSHIP TO NATIONAL VISION (Brenda Bateman \& Racquel Rancier eds., 2012), available at http://www.awra.org/committees/AWRA-Case-StudiesIWRM.pdf; Hoffman \& Zellmer, supra note 74. 
scales, including making trade-offs among competing policy goals. ${ }^{113}$

Moreover, water law's fragmented features are maladaptive because they impede adaptive responses to cross-scale or complex disturbances to water systems. Adaptation often requires use of networks across institutional and disciplinary silos, some degree of cooperation among many stakeholders in water resources and systems, and the coordinated, yet experimental, use of multiple methods or instruments to respond to threats, risks, and disturbances. One example is the integration of surface water and groundwater rights and regulations. Another is coordination among TMDLs, MS4 permits, NPDES permits, USDA land and water conservation programs, local land-use planning and regulation, water-quality trading systems, public education, watershed planning and governance, forestry management, wetlands protections, and other legal regimes that affect water runoff and water quality. The fragmented structure of water law is not merely polycentric and modular. It is a system of legal silos that inhibit cross-scale, cross-function, cross-modal coordination or loose integration.

\section{A FRAMEWORK OF ADAPTIVE LAW}

U.S. institutions governing water resources need frameworks of adaptive rules and procedures that enhance institutional and societal capacity to adapt to changing conditions and unexpected disturbances. Recent scholarship on water resources and social-ecological resilience offers a variety of frameworks that can improve the adaptive capacity of water institutions. These include adaptive water governance, ${ }^{114}$ adaptive water planning, ${ }^{15}$ adaptive management of aquatic ecosystems, ${ }^{116}$ climate change adaptation principles, ${ }^{117}$ and adaptive administrative law. ${ }^{118}$ All of these works both acknowledge substantial obstacles to achieving adaptive institutional capacity, yet offer important and promising proposals for legal reform.

Adaptive capacity must be built into the legal system as a whole, not just specific resource management mandates or decision making

113. Holly Doremus, CALFED and the Quest for Optimal Institutional Fragmentation, 12 ENVTL. SCI. \& POL'Y 729 (2009).

114. See Cosens \& Williams, supra note 60; Per Olsson et al., supra note 60.

115. See Arnold, supra note 33, at 421, 439-40.

116. See Angelo, supra note 57.

117. See DiscontinUitiEs In ECOSYSTEMS, supra note 35.

118. See Craig \& Ruhl, supra note 58. 
processes. Starting with this premise, resilience ecologist Lance Gunderson and I developed a framework of structural features of an adaptive legal system. Our "adaptive law" framework was published in a 2013 article in the Environmental Law Reporter ${ }^{119}$ and a chapter of a 2014 book published by Columbia University Press, Social-Ecological Resilience and Law, edited by Ahjond S. Garmestani and Craig R. Allen. ${ }^{120}$ This framework has four categories: adaptive goals, adaptive structure, adaptive methods, and adaptive processes. ${ }^{121}$

\section{A. Adaptive Goals}

Adaptive law aims to achieve multiple co-existent forms of resilience, a concept known as poly-resilience. ${ }^{122}$ In particular, a legal system that is adaptive to change serves to strengthen the adaptive capacity of both social systems, including institutions and communities, and ecological systems (or ecosystems). ${ }^{123}$ This is because the healthy functioning and adaptive capacity of various aspects of society-the economy, the political system, culture, and the like - and the healthy functioning and adaptive capacity of various ecosystems - such as watersheds, forests, and wetlands-are interdependent. ${ }^{124}$ If the legal system aims to advance the particular stability of just a single system, it risks harming all systems and contributing to the decline and collapse of both natural and human communities. ${ }^{125}$

Much of the U.S. legal system today gives primacy to political goals, such as liberty or the diffusion of power, or economic goals, such as economic productivity and the efficient allocation and exchange of resources. ${ }^{126}$ These are worthwhile goals, but a single-minded focus on these goals can lead to ecological disaster, which in turn can threaten economies, communities, and political institutions. ${ }^{127}$ Hurricane Katrina's devastation of New Orleans, ${ }^{128}$ the Deep Horizon BP oil spill in

119. Arnold \& Gunderson, supra note 39.

120. Craig Anthony (Tony) Arnold \& Lance H. Gunderson, Adaptive Law, in SocIALECOLOGICAL RESILIENCE AND LAW 317 (Ahjond S. Garmestani \& Craig R. Allen eds., 2014).

121. Arnold \& Gunderson, supra note 39, at 10428-42.

122. Id. at $10428-32$.

123. Id.

124. Id.

125. Id.

126. Id.

127. Id. at $10427-32$.

128. See R. W. Kates et al., supra note 43. 
the Gulf of Mexico, ${ }^{129}$ and losses from wildfires enabled by landdevelopment practices and fire suppression ${ }^{130}$ come to mind as examples. However, single-minded focus on environmental goals without regard to the effects of environmental protection laws on people and their welfare can backfire and eventually lead to more environmental harm when political forces push back against laws or when local economies decline, thereby reducing available resources with which to engage in conservationist behaviors. ${ }^{131}$

\section{B. Adaptive Structure}

An adaptive law system is polycentric, diversifying exposure to risk, creating redundancies that can absorb shock, and facilitating adaptive innovation by spreading power and authority among multiple centers. ${ }^{132}$ Power and authority are not concentrated in a single center, such as the federal government or the legislative branch, regardless of the temptation to overcome the perceived ineffectiveness of diffused power. ${ }^{133} \mathrm{~A}$ mistake or misjudgment by a single all-powerful entity, which is virtually inevitable given the cognitive and organizational limitations of humans, is likely to create a cascade of failure and collapse throughout multiple, interconnected systems. ${ }^{134}$ In contrast, polycentric systems make it harder for failure and collapse to spread. ${ }^{135}$ An adaptive law system also uses multiple modes, methods, and instruments to address problems at multiple scales, instead of selecting a single "optimal" mode, method or instrument that has the potential to fail or a single scale of governance that could be mismatched to the multiscalar features of complex problems. ${ }^{136}$ There are no panaceas in an adaptive governance system - no cookie-cutter, one-size-fits-all, magic-bullet solutions. ${ }^{137}$ However, an adaptive law system aims for loose integration among the multiple centers and scales of governance and the multiple methods or

129. See Brian R. Silliman et al., Degradation and Resilience in Louisiana Salt Marshes after the BP-Deepwater Horizon Oil Spill, 109 Proc. NAT'L ACAD. SCI. 11234 (2012).

130. See F. Stuart Chapin III et al., Planning for Resilience: Modeling Change in Human-Fire Interactions in the Alaskan Boreal Forest, 1 FrONTIERS ECOLOGY \& ENV'T 255 (2003).

131. Arnold \& Gunderson, supra note 39 , at 10428-32.

132. Id. at $10432-35$.

133. Id.

134. Id.

135. Id.

136. Id. at $10434-36$.

137. Id. at 10434. See also Elinor Ostrom et al., Going Beyond Panaceas, 104 Proc. NAT'L ACAD. SCI. 15176 (2007). 
instruments that are used, in contrast to the relatively fragmented characteristics of a maladaptive legal system. ${ }^{138}$

\section{Adaptive Methods}

An adaptive law system facilitates social and ecological resilience through moderate evolution in rules, standards, processes, and structures as the system adapts to changing conditions. ${ }^{139}$ Change is neither resisted nor undertaken quickly and sweepingly. ${ }^{140}$ An adaptive law system uses context-regarding standards and flexible discretionary decision making, in contrast to legal abstractions, rigid rules, and excessive limits on action and authority. ${ }^{141}$ An adaptive law system also has a high tolerance for uncertainty, whereas the current legal system in the U.S. tends to demand certainty. ${ }^{142}$ Attempts to achieve certainty of outcomes, adhere to universally applicable rules, and prevent abuses of power are maladaptive when they fail to recognize that decision makers and actors need flexibility, discretion, and authority to respond to new situations, adapt to changing conditions, and experiment with various possible solutions to public problems. ${ }^{143}$

\section{Adaptive Processes}

An adaptive law system recognizes and embraces iterative processes among multiple participants, instead of linear decision making and implementation processes by a single authority. ${ }^{144}$ An adaptive law system recognizes limits to human and organizational rationality and the effects of social and ecological forces on the ordering and management of human affairs, whereas a maladaptive law system presumes that all decision making is rational and that the law is central to the ordering and management of human affairs. ${ }^{145}$ However, there are many potential adverse effects from bounded human knowledge and rationality and the broad discretion of decision makers and actors in iterative processes that

\footnotetext{
138. Arnold \& Gunderson, supra note 39, at 10434-36.

139. Id. at $10436-38$.

140. Id.

141. Id.

142. Id. at $10427,10436-38$.

143. Id. at $10436-38$.

144. Id. at 10438-42.

145. Id.
} 
are not tightly constrained by law. ${ }^{146}$ An adaptive law system limits these effects by: a) mandating feedback loops by which the effects of decisions and actions are monitored and evaluated, lessons learned, and decisions or actions altered on the basis of lessons learned, and b) utilizing accountability mechanisms for the conservation of natural, human, social, political, and economic capital so that the functions of the basic infrastructure that supports nature and society are not impaired. ${ }^{147}$

A table summarizing the features of an adaptive law framework, and contrasting them with a maladaptive legal system appears below:

Table 1: Comparison of Features of Maladaptive Law and Adaptive Law ${ }^{148}$

\begin{tabular}{|c|c|c|}
\hline Feature & Maladaptive Law & Adaptive Law \\
\hline Goals & $\begin{array}{l}\text { Legal regimes aim to } \\
\text { advance particular stability } \\
\text { of single systems. Current } \\
\text { regimes focus primarily on } \\
\text { political and economic } \\
\text { goals. Alternative (reform) } \\
\text { regimes focus primarily on } \\
\text { ecological goals. }\end{array}$ & $\begin{array}{l}\text { Legal regimes aim for multiple forms } \\
\text { of resilience: the resilience and } \\
\text { adaptive capacity of both social and } \\
\text { ecological systems, including } \\
\text { constituent subsystems, such as } \\
\text { institutions and communities. }\end{array}$ \\
\hline Structure & $\begin{array}{l}\text { Law is monocentric, } \\
\text { utilizing fragmented and } \\
\text { unimodal responses to } \\
\text { problems. }\end{array}$ & $\begin{array}{l}\text { Law is polycentric, utilizing } \\
\text { multimodal and multiscalar responses } \\
\text { to problems that are loosely } \\
\text { integrated. }\end{array}$ \\
\hline Methods & $\begin{array}{l}\text { Law controls society } \\
\text { through rules, limits on } \\
\text { action and authority, } \\
\text { demand for certainty, and } \\
\text { legal abstractions that } \\
\text { resist change. }\end{array}$ & $\begin{array}{l}\text { Law facilitates social and ecological } \\
\text { resilience through } \\
\text { moderate/evolutionary adaptation to } \\
\text { changing conditions, context- } \\
\text { regarding standards, tolerance for } \\
\text { uncertainty, and flexible } \\
\text { discretionary decision making. }\end{array}$ \\
\hline Processes & $\begin{array}{l}\text { Law presumes rational, } \\
\text { linear decision-making and } \\
\text { implementation processes } \\
\text { by a single authority and } \\
\text { the centrality of law to the } \\
\text { ordering and management } \\
\text { of human affairs. }\end{array}$ & $\begin{array}{l}\text { Law recognizes and embraces } \\
\text { iterative processes with feedback } \\
\text { loops among multiple participants, } \\
\text { limits to human and organizational } \\
\text { rationality, and the effects of social } \\
\text { and ecological forces on the ordering } \\
\text { and management of human affairs, } \\
\text { and accountability mechanisms for } \\
\text { the conservation of capital. }\end{array}$ \\
\hline
\end{tabular}

146. Id.

147. Id.

148. Reproduced from Arnold \& Gunderson, supra note 39, at 10428. 


\section{THE RESILIENT FUTURE: ADAPTIVE WATER LAW}

The adaptive law framework has great potential application to water law and the evolution of water law towards a more adaptive governance regime. An adaptive water law regime that facilitates the resilience of communities and their waters, including the healthy functioning of watersheds and water bodies, is characterized by at least three features: 1) shared risk among the stakeholders in a watershed and its waters; 2) conditional and flexible standards; and 3) integrated water governance. There are several other possible characteristics of an adaptive water law regime, which are beyond the scope of this particular article. However, the three features that receive focused attention in this article contrast with the water law system's maladaptive features of false security, rigid rules, and fragmented governance.

\section{A. Shared Risk}

An adaptive water law regime prompts and facilitates the sharing of risks by all stakeholders in a water system. Risk avoidance and reduction are, in general, good strategies for a resource management system. However, risk is inevitable, difficult to predict, and challenging to manage in complex and dynamic systems, as Sections II.A and II.B of this article describe. Moreover, all stakeholders in a water system will inevitably share in exposure to those risks, in one way or another. Both climate change and contemporary water demand-supply dynamics have effects that cannot be merely avoided or reduced through rules.

Water transcends any single system for governing it and managing risks to the resource and its users. Water is not a purely private resource, a purely public resource, or a purely common resource. If it were a purely private resource, risks would be managed through property rules and market transactions. ${ }^{149}$ If it were a purely public resource, risks would be managed through government policies and controls. ${ }^{150}$ If it were a purely common resource, risks would be managed by commonpool governance mechanisms like those studied by Nobel Laureate

149. See Terry L. Anderson, Water Markets: Priming the InVisible Pump (1997); Terry L. ANDERSOn \& Donald R. LEAL, FREE MARKET ENVIRONMENTALISM (2001).

150. See Eric T. Freyfogle, Water Rights and the Common Wealth, 26 ENvTL. L. 27 (1996); Itzchak E. Kornfeld, Water: A Public Good or a Commodity?, 106 AM. SoC'y INT'L L. PROC. 49 (2012); Sax, supra note 83. 
Elinor Ostrom. ${ }^{151}$ Water has private, public, and common characteristics, though. ${ }^{152}$ Risk-sharing mechanisms that work across different types of resource management regimes can enhance the adaptive capacity of water institutions.

Shared-risk systems and processes are necessary to balance and integrate the many critical functions that water provides to society. Water is essential to all biological life, yet it is also essential to economic activity, the vitality of communities, and the functioning of ecological systems. ${ }^{153}$ The breadth and importance of many different functions of water deter the development of a single governance or risk-management regime.

Moreover, water is fluid, of course. It does not remain in a single form or location and thus does not remain within the bounds of any particular type of governance regime. Any given molecules of water move readily and even frequently among surface water bodies, groundwater, land, the atmosphere, organisms, and human-created systems (e.g., manufacturing processes, drinking-water or wastewater pipes, irrigation sprinklers).

The risks from severe or prolonged drought, for example, will involve surface water flows and supplies, groundwater, runoff, wetlands, riparian lands and vegetation (including invasives and hydrophytes), evaporation and transpiration dynamics, demands from various users, and the like. Thus, efforts to manage the risks will occur in many legal regimes, but none of the regimes will have adequate control over the problem to govern the risk. These regimes include: private and public rights in surface waters (e.g., prior appropriation or regulated riparian systems; public trust doctrine; state ownership doctrine; federal navigation servitude; takings); private and public rights in groundwater; common-pool management systems for surface waters and/or groundwater; federal, state, and local government regulation of water

151. See Elinor Ostrom, Governing the Commons: The Evolution of InStitutions For Collective ACtion (1990).

152. James Quilligan, Public Goods vs Common Goods, P2P Foundation (Aug. 11, 2011), http://p2pfoundation.net/Public_Goods_vs_Common_Goods; see also Craig Anthony (Tony) Arnold, Water Privatization Trends in the United States: Human Rights, National Security, and Public Stewardship, 33 WM. \& MARY ENVTL. L. \& POL'Y ReV. 785, 805-08 (2009).

153. Thomas E. Davenport, The Watershed Project Management Guide 21-35 (2003); Craig Anthony (Tony) Arnold, Sustainable Webs of Interest: Property in an Interconnected Environment, in PROPERTY RIGHTS AND SUSTAINABILITY: THE EVOLUTION OF PROPERTY RIGHTS to MeEt ECological Challenges 167, 182 (David Grinlinton \& Prudence Taylor eds., 2011); Sandra Postel \& Stephen Carter, Freshwater Ecosystem Services, in NATURE's SERVICES: SOCIETAL DEPENDENCE ON NATURAL ECOSYSTEMS 195 (Gretchen C. Daily ed., 1997). 
pollution; federal, state, and local government regulation of wetlands in the context of private property rights in land; the complex mix of regulatory and non-regulatory efforts to control runoff in the context of private property rights in land; state and local land-use plans and regulations; local and private water supply management plans and policies; policies and rules governing dams, reservoirs, and other waterworks; other environmental laws protecting aquatic resources (e.g., the Endangered Species Act); and so forth. Thus, risks to aquatic systems transcend any single legal or governance regime.

Rules do not secure certainty of risks and risk allocation well in complex, interconnected, dynamic sets of systems, like those affecting water resources. For example, the prior appropriation system attempts to allocate the risks of water shortages in rivers in order of priority in time, from the most junior appropriators to the most senior appropriators. In reality, this risk allocation system is often ignored, is circumvented at least to some degree, or fails. ${ }^{154}$ This is due to the complexities of return flows, the locations of various appropriators' withdrawals, the administrative difficulties of seniors enforcing their rights against juniors, surface water-groundwater interactions (including seepage), the effects of hydrophytes and evaporation, changing streambed and streambank characteristics, and various public policy considerations that can override the legal rules. ${ }^{155}$ Water users often find themselves sharing the risks of water shortages in reality, regardless of the seemingly applicable rules. ${ }^{156}$

Likewise, the water problems of Las Vegas, described in the Introduction of this article, illustrate the inadequacies of legal rules as fortresses against future uncertainties. Whether Las Vegas should have been built in its very arid location or allowed to grow as it has is beside the point now. The reality is that Las Vegas needs water under conditions of supply instability and shrinking supplies, and that our political system is not going to let Las Vegas go dry, given its size and cultural and economic importance nationally. Las Vegas's water problems are now the problems of all the signatories to the Colorado River Compact, regardless of whether it's fair, environmentally unsustainable, or legally mandated. Likewise, Las Vegas's water problems are now the problems of eastern Nevada rural communities,

154. See A. Dan Tarlock, The Future of Prior Appropriation in the New West, 41 NAT. RES. J. 769 (2001).

155. Id.

156. Id. 
regardless of who wins or loses Las Vegas's current efforts to secure groundwater pumping rights. By the same token, though, Las Vegas shares in the risks of over-pumping eastern Nevada groundwater, including the impacts on the long-term sustainability of those water supplies, the environment, and the local communities.

An adaptive law regime has to address questions of fairness, environmental sustainability, community impact, efficient use of resources, individual rights, and the like. It must aim to avoid or reduce unnecessary risks. It performs these functions, though, by expressly acknowledging and facilitating the affected parties' sharing of risk, not by trying to prevent change and secure a false certainty about resource arrangements.

One element of an adaptive law regime that facilitates sharing of risks is to reduce the use of property rights as after-the-fact insurance policies against change or as opt-outs from sharing risks. This idea does not call for the elimination of private property rights or the "decline" of private property. ${ }^{157}$ Private property rights can be highly adaptive features of the socio-legal system if they are flexible and evolve over time, ${ }^{158}$ and government controls over resources can at times be less adaptive than private use and management of resources. However, rigid and unchangeable property rights are poorly suited to changing conditions and the capacity of linked social-ecological systems to adapt to significant disturbances. The legal system must embrace modifications in property rights that are necessitated by changed environmental and social conditions that are experienced by interestholders generally. It must also differentiate between: a) compensable takings of private rights by the government to benefit some interests over others, and b) non-compensable adjustments to private rights due to changing social and environmental conditions that are part of the bargain of holding property interests in a dynamic social-environmental system. Private property rights are not guarantees against social-ecological change.

Another element of an adaptive law regime is to use multiparticipant watershed governance systems to facilitate risk-sharing.

157. See Joseph L. Sax, Some Thoughts on the Decline of Private Property, 58 WASH. L. REV. 481 (1983).

158. For prior publications arguing for a flexible, evolutionary, context-regarding body of property law, see Arnold, supra note 64; Arnold, supra note 153; Craig Anthony (Tony) Arnold, The Reconstitution of Property: Property as a Web of Interests, 26 HARV. EnVTL. L. Rev. 281 (2002). 
Many of the risks that people, organizations, and communities share in linked social-ecological aquatic systems are encountered at watershed scales and involve watershed processes and functions. Many watershed governance systems involve some degree of collaborative problem solving in the context of uncertainty, disturbances to water resources in the watershed, and risks shared by many interests. ${ }^{159}$ Multi-participant watershed planning, management, and governance processes can produce many different actions aimed at enhancing the overall adaptive capacity of the watershed and its communities, economies, and stakeholders. These actions include shared reductions of water uses in times of drought, ${ }^{160}$ water transfers, ${ }^{161}$ adaptive restoration of watershed features, ${ }^{162}$ water-quality credit trading systems, ${ }^{163}$ riparian or aquiferrecharge-zone land conservation, ${ }^{164}$ new land-use controls, ${ }^{165}$ shared pollution or runoff reduction efforts, ${ }^{166}$ the use of green infrastructure, ${ }^{167}$ water-use conservation methods, ${ }^{168}$ water supply planning under

159. See, e.g., SWimming UpSTREAM: Collaborative APPROACHES to WATERShed MANAGEMENT (Paul A. Sabatier et al. eds., 2005).

160. The Blackfoot Challenge: Working with local ranchers to create a Drought Response Plan, ClimateChangeMt.org, http://www.climatechangemt.org/focus-crown-of-the-continent/successstories-2/blackfoot-challenge-2/ (last visited Mar. 01, 2014) (voluntary shared reduction of water use during times of drought).

161. John J. Ferguson et al., Keeping Fish Wet in Montana: Private Water Leasing: Working within the Prior Appropriation System to Restore Streamflows, 27 PUB. LAND \& RES. L. REV. 1 (2006).

162. The Comprehensive Everglades Restoration Plan (CERP), http://www.everglades plan.org/ (last visited Mar. 01, 2014); ROBERT W. ADLER, RESTORING COLORADO River ECOSYSTEMS: A TROUBLED SENSE OF IMMENSITY (2007).

163. Ohio River Basin Trading Project, ELEC. POWER RESEARCH INST., http://wqt.epri.com/ (last visited Mar. 01, 2014).

164. Riparian Conservation, ClEARWATER CONSERVANCY, http://www.clearwaterconservancy. org/programs_and_initiatives/riparian_conservation (last visited Mar. 01, 2014); Recharge Zone Protection and Management, EDWARDS AQUIFER AUTHORITY, http://edwardsaquifer.org/rechargezone-protection (last visited Mar. 01, 2014).

165. City of Olympia, Washington, Low-Impact DeVelopment Strategy for Green Cove Basin: A Case Study in Regulatory Protection of Aquatic Habitat in Urbanizing WATERSHEDS (2002), available at http://www.psparchives.com/publications/our_work/stormwater/ lid/ordinances/Green_Cove.pdf.

166. Our Missouri Waters, MO DEP’T OF NATURAL RES., https://www.dnr.mo.gov/omwi.htm (last visited Mar. 01, 2014) (state program focused on local watershed-based plans and projects for shared runoff and pollution reductions).

167. See Green City, Clean Waters, PhiladelPhia Water Department, http://www.philly watersheds.org/what_were_doing/documents_and_data/cso_long_term_control_plan (last visited Mar. 01, 2014).

168. ROARING Fork CONSERVANCY, OPPORTUNITIES FOR WATER CONSERVATION: REALIZING THE STREAMFLOW BENEFITS FROM LOCAL WATER CONSERVATION EFFORTS (2012), available at http://www.roaringfork.org/pub/collaborative/RFC\%20Water\%20Conservation\%20Report\%20Final $\% 204.12 .12$.pdf. 
conditions of uncertainty and change, ${ }^{169}$ and others. The basic premise is that risks to the linked social-ecological systems in the watershed are collective risks that must be addressed collectively.

A shared-risk management approach to water law meets the criteria of an adaptive law system. First, it addresses both risks to and the resilience of multiple systems, both ecological and social, thus facilitating pursuit of poly-resilient goals. Second, a shared-risk management approach requires the use of multiple risk management methods at multiple scales of disturbance and multiple levels or centers of governance. Thus, it makes use of an adaptive legal structure. Third, shared-risk management methods necessarily have a reasonable tolerance for uncertainty, require flexibility, and adapt over time to changing conditions, all of which are adaptive methods of resource governance. Finally, a shared-risk management approach features iterative processes of both cooperation among multiple participants and risk management decision making and implementation, ideally with feedback loops that allow decision makers to learn from the effects of their decisions under dynamic and complex conditions and make adjustments to their risksharing strategies. Thus, it utilizes adaptive processes.

\section{B. Conditional and Flexible Standards}

An adaptive law framework uses conditional and flexible standards, instead of rigid rules. Institutions cannot adapt to disturbances or changes if their decision makers lack discretion and flexibility, because they are bound by rigid, narrow rules. Decision makers need authority and flexibility to: a) consider the broad ecological and social contexts of their decisions, including multiscalar relationships and dynamics; b) address potential risks, multiple possible scenarios or models, and the resilience of both ecological and social systems; and c) experiment with possible management or governance options, adapting as they learn from monitoring and assessing the effects of their decisions and actions. ${ }^{170}$

While rigid rules prevent adaptive behaviors and give a false sense of security that particular social-ecological outcomes will be maintained, they also prevent abuses of discretion by resource managers. An adaptive law regime does not embrace standard-less discretion and

169. Santa Ana Watershed Project Authority, One Water, One Watershed: 2010 SANTA ANA INTEGRATED WATERSHED PLAN, ch. 5.9 (2010), available at http://www.sawpa.org/ owow-1-0-2/.

170. Arnold \& Gunderson, supra note 39, at 10436. 
flexibility. ${ }^{171}$ Instead, adaptive law requires that decisions and actions are adaptive and conform to standards that enhance the resilience of both ecosystems and social systems. In other words, adaptive law embraces principled flexibility. ${ }^{172}$ Standards for discretionary decisions and adaptive management actions guard against decision makers' abuses of discretion and decisions that do not comport with the applicable goals for water governance. At the same time, principled standards do not predetermine or pre-restrict actions with fixed, narrow, inflexible rules.

There are several measures by which to develop and apply principled standards governing water resources. They include:

1) predicted or known thresholds or tipping points at which ecosystems or linked social-ecological systems decline and transform to a different state ${ }^{173}$

2) performance measures based on ecosystem function or social-ecological function, including the authority for planners, managers, resource users, and regulated parties to select from menus of option based on performance outcomes; ${ }^{174}$

3) precautionary or no-regrets standards; ${ }^{175}$

4) co-benefits standards that aim for multiple ecological and social benefits; ${ }^{176}$ and

5) the public trust doctrine, which requires conservation of both natural and social capital in water resources, provided that the public trust doctrine is actually implemented in water resource decisions. ${ }^{177}$

171. Annecoos Wiersema, A Train Without Tracks: Rethinking the Place of Law and Goals in Environmental and Natural Resources Law, 38 ENVTL. L. 1239 (2008).

172. Craig, supra note 46.

173. See Ahjond S. Garmestani \& Melinda Harm Benson, A Framework for Resilience-based Governance of Social-Ecological Systems, 18(1) ECOLOGY \& SOC'Y 9 (2013).

174. See J.B. Ruhl \& Robert Fischman, Adaptive Management in the Courts, 95 MinN. L. REv. 424 (2010).

175. See Craig, supra note 46.

176. Arnold \& Gunderson, supra note 39, at 10436.

177. For arguments for a robust public trust doctrine as an adaptive standard aimed at the resilience of linked social-ecological systems, see MARY ChrISTINA WOOD, NATURE'S TRUST: ENVIRONMENTAl LAW FOR A NeW ECOLOGICAL AGE (2013); Arnold \& Gunderson, supra note 39, 
Another means of using conditional and flexible standards is to make all water-use and water-quality permits time-limited, conditional permits that are renewable but revisable at the renewal period. Permitting agencies could tailor the conditions of the permit to the ecological and social context of the proposed water use or discharge, specifically including adaptive conditions and conditions that facilitate socialecological resilience. If permit holders are required to seek renewal periodically, permitting agencies could make adjustments to the permitted activities as required by changed conditions or new information learned from implementing the permit. Florida's regional water management districts issue conditional, time-limited, renewable, and revisable water permits, ${ }^{178}$ and some land-use regulatory authorities follow this practice for conditional land-use permits. ${ }^{179}$

Change from rigid rules to flexible standards is already underway. The rigidity of prior appropriation rules is eroding. Priority is rarely strictly enforced as a practical matter, despite the persistence of the rule itself. ${ }^{180}$ Recently, Reed Benson has called our attention to three western water cases that infuse more flexibility into water rights than the strict application of the prior appropriation doctrine would allow; he argues that the traditional rules of prior appropriation are not dead but are increasingly irrelevant as water law evolves. ${ }^{181}$

Conditional and flexible standards are adaptive discretionary methods within the adaptive law framework: context-regarding standards, flexible, discretionary decision making, and moderate or evolutionary adaptation to changing conditions. Principled standards provide accountability to poly-resilient goals (e.g., the conservation of both natural capital and social capital) and provide the metrics against which water governance decisions and methods can be evaluated via

at 10441-42; Arnold, supra note 152, at 789. For discussions of the obstacles to implementation of the public trust doctrine, see Craig Anthony (Tony) Arnold, Working Out an Environmental Ethic: Anniversary Lessons From Mono Lake, 4 Wyo. L. Rev. 1 (2004); Dave Owen, The Mono Lake Decision, the Public Trust Doctrine, and the Administrative State, 45 U.C. DAVIS L. REV. 1099 (2012).

178. See, e.g., e-Permitting, ST. JOHN's RIVER WATER MANAGEMENT DistRICT, http://www.sjrwmd.com/permitting/ (last visited Mar. 03, 2014).

179. The City of Anaheim, California, followed this practice for conditional use permits (CUPs) when the author served on the Anaheim Planning Commission. Professor Arnold served on the Anaheim Planning Commission from 1999 to 2002.

180. See A. Dan Tarlock, Prior Appropriation: Rule, Principle, Or Rhetoric?, 76 N.D. L. Rev. 881, 894 (2000); Tarlock, supra note 154.

181. Reed Benson, Alive but Irrelevant: The Prior Appropriation Doctrine in Today's Western Water Law, 83 U. COLO. L. ReV. 675 (2012). 
feedback loops and iterative decision-making processes. Polycentric, multimodal, multiscalar, and integrated water governance structures function better when they employ conditional and flexible standards rather than when they are constrained by rigid rules.

\section{Integrated Water Governance}

Adaptive water law facilitates integrated governance of water resources in at least three respects: 1) governance and management of water, land, and the environment at scales at which social systems and ecosystems interact and affect one another; 2) involvement of all the participants-public and private, individuals and organizations, regulators, managers, users, and advocates - in water system governance (sometimes called multi-stakeholder participation); and 3) flexible but coordinated use of multiple methods and tools for adaptively governing, managing, and conserving water resources, including adaptive planning, regulatory, legal, market, educational, and adaptive management tools, among others.

These concepts appear in Integrated Water Resources Management (IWRM). ${ }^{182}$ IWRM's fourteen principles include the integration of water management, environmental management, and land-use planning "conjunctively with codependent natural resources, namely soil, forests, air and biota." $" 183$ It uses a systems approach that is attentive to individual components, interdependent linkages, and the role of disturbances and resilience. It calls for: "full participation by all stakeholders" in transparent, accountable, adaptive, and locally-based decision making; attention to the social impacts of water policies; improvement of information availability, information use, and institutional capacity; the equitable allocation of water resources; and regard for the "hydrological, bio-physical, economic, social and environmental characteristics of a catchment" when making decisions, among others. ${ }^{184}$ However, the term "management" in IWRM suggests that it is focused primarily or solely on management actions, instead of a broader set of governance structures and legal decisions. Recent work on adaptive water planning and

182. See AM. WAter ReS. Ass'N, supra note 112; Jeffry S. Wade, Privatization and the Future of Water Services, 20 FLA. J. INT'L L. 179, 192-96 (2008). For an excellent discussion of the opportunities and barriers to integrated management of groundwater and surface water, using Colorado, Kansas, and Nebraska as case studies, see Hoffman \& Zellmer, supra note 74.

183. Wade, supra note 182, at 194.

184. Id. at 194-96. 
adaptive water governance incorporates many IWRM principles but focuses on broader governance institutions. ${ }^{185}$

Water resource governance institutions need to be organized at geographic scales at which feedback loops among various ecosystemsaquatic, terrestrial, climate, and others - and various social systemspolitical systems, water-resource economies, local communities, and others-intersect with one another. Experts have long argued that resource management and regulation should occur at ecosystem scales. ${ }^{186}$ In particular, experts have argued for water governance and management at watershed scales. ${ }^{187}$ Watersheds are aquatic ecosystems organized in nested scales from small catchments to large river basins, thus allowing for multiscalar governance structures that match governance functions with the appropriate geographic scale of the problems and socialecological dynamics that need to be addressed. ${ }^{188}$ Disturbances to water resources and changing water conditions can best be addressed at watershed scales where societal and ecological systems interact. The development of watershed governance institutions enhances the adaptive capacity of society to address many interconnected aspects and functions of nature and society.

Adaptive water law also engages many stakeholders in water governance and builds participatory networks that give these institutions legitimacy, greater opportunities for problem-solving innovations, and

185. See ADAPTIVE GovernANCE, supra note 60; Arnold \& Gunderson, supra note 39; Cosens \& Williams, supra note 60; Dave Huitema, et al., Adaptive Water Governance: Assessing the Institutional Prescriptions of Adaptive (Co-) Management from a Governance Perspective and Defining a Research Agenda, 14(1) ECOLOGY \& SoC'Y 26 (2009); Per Olsson et al., supra note 60.

186. See Blair et al., supra note 111; Karkkainen, supra note 111, at 212.

187. Some of the best works on the topic include: Robert W. Adler, Addressing Barriers to Watershed Protection, 25 ENVTL. L. 973 (1995); Robert W. Adler \& Michele Straube, Watersheds and the Integration of U.S. Water Law and Policy: Bridging the Great Divides, 25 WM. \& MARY ENVTL. L. \& POL'Y REV. 1 (2000); Arnold, supra note 33; Jon Cannon, Choices and Institutions in Watershed Management, 25 WM. \& MARY ENVTL. L. \& POL'Y REV. 379 (2000); Keith H. Hirokawa, Driving Local Governments to Watershed Governance, 42 ENVTL. L. 157 (2012); Klein, supra note 78, at 1015-17; Janet C. Neuman, Dusting Off the Blueprint for a Dryland Democracy: Incorporating Watershed Integrity and Water Availability into Land Use Decisions, in WET Growth, supra note 105, at 119-69; J.B. Ruhl et al., Proposal for a Model State Watershed Management Act, 33 ENVTL. L. 929 (2003); Tarlock, supra note 111. The idea is not new. Famous explorer and scientist, John Wesley Powell, proposed to Congress in 1878 that the West be organized politically around watersheds due to the strong relationships among water, land use, communities, and society. See John Wesley Powell, Report of the Lands of the Arid Region of the United States, With a More Detailed Account of the Lands of Utah, H.R. Exec. Doc. No. 45-73 (2d Sess. 1878).

188. See Arnold, supra note 33. 
improved capacity to implement solutions and policies adaptively. ${ }^{189}$ Integration of participation does not mean that a governance system is solely or primarily bottom-up or consensus-based. Integrated participatory approaches can be used with top-down and hybrid topdown/bottom-up processes. Hybrid processes and structures tend to characterize watershed planning, management, and governance, despite the mistaken tendency to think of these processes as purely grassroots collaboration. Moreover, iterative processes of participation include cycles or even mixes of cooperation, legal conflict (e.g., litigation), political conflict (e.g., legislative or regulatory decisions), and semiautonomous action (e.g., voluntary conservation measures). Nonetheless, Cosens and Stow have argued that the construction and maintenance of entity and stakeholder networks in linked water systems help to build and maintain system resilience and the adaptive capacity of the governance institutions. ${ }^{190}$ Moreover, recent empirical research suggests that collaborative watershed management contributes to implementation of TMDLs. ${ }^{191}$

Adaptive water law also integrates the use of multiple methods, tools, and instruments for governing water resources. This approach has been called "integrationist multimodality" or a coordinated toolbox approach to resource issues. ${ }^{192}$

Integrationist multimodality is the use of multiple modes or methods of achieving a policy goal in a way that integrates or interconnects these multiple modes or methods. I have posited that integrationist multimodality is a new, emerging generation of environmental law and policy, which has previously been unimodal and fragmented, and consequently, maladaptive and inadequate. Unimodality is the choice of a particular mode, instrument, method, or design as "optimal" and is frequently characterized by advancement of a particular model or uniform, one-size-fits-all approach. For example, the classic debate

189. Many authors have addressed the importance of participatory structures and processes to adaptive water governance. See, e.g., Edella Schlager \& William BlomQuist, EMBRacing WATERSHED POLITICS (2008); SWIMMING UPSTREAM, supra note 159; Arnold \& Gunderson, supra note 39; Barbara A. Cosens \& Craig A. Stow, Resilience and Water Governance: Addressing Fragmentation and Uncertainty in Water Allocation and Water Quality Law, in SOCIALECOLOGICAL RESILIENCE AND LAW, supra note 120, at 142-75; Cosens \& Williams, supra note 60.

190. Consens \& Stow, supra note 189 , at 155-170.

191. John Hoornbeek et al., Implementing Water Pollution Policy in the United States: Total Maximum Daily Loads and Collaborative Watershed Management, 26 SOC'Y \& NAT. RES. 420 (2013).

192. ARNOLD ET AL., supra note 32; Arnold, supra note 104. 
regarding the effectiveness of command-and-control regulations versus market mechanisms is a unimodal choice. However, many examples of unimodality are more fine-grained: model statutes or ordinances, standard design or management procedures, uniform laws, the new preferred program or policy of the day, and so forth. In contrast, "multimodality" is a tool-box approach. It facilitates multiple actors' selections from a variety of instruments, methods, and tools to respond to complex problems. ${ }^{193}$ Moreover, these multiple modes can be, and often are, linked, although uniformly tight linkages - true integration-can transmit disturbances and shocks throughout the system, producing cascade effects that lead to system decline or collapse. Loose connections or networks - integrationist, rather than integrated-offer coordination and synergy while reducing the risk of weakness contagion. $^{194}$

Integrated water governance manifests the adaptive law framework in many respects. It focuses on the integrated effort to improve resilience and adaptive capacity in ecosystems, especially watersheds, and social systems, especially those with tight links to water resources. Thus, it advances poly-resilient goals. It is adaptively structured around multiple scales (especially multiple scales of watersheds) and the loosely integrated use of multiple governance methods or instruments. Integrated water governance could theoretically be monocentric, centralized in a single federal government agency, for example. However, in practice, the multiscalar and multi-participant nature of integrated water governance means that it is actually polycentric, as evidenced by the large number of watershed governance institutions across the U.S. However, these watershed governance institutions seek and often do transcend (at least partially) the organizational, political, and disciplinary silos created by traditional water law and water governance systems. Integrated water governance also uses iterative processes with feedback loops among multiple participants and addresses the effects of social and ecological forces in the management of human affairs, instead of overestimating the ability of law and governance institutions to control social-ecological dynamics. Integrated water governance enhances institutional, social, and ecological adaptive capacity by organizing around the interconnections in ecosystem-social legal-system dynamics.

193. ARNOLD ET AL., supra note 32; Arnold, supra note 104.

194. Arnold \& Gunderson, supra note 39, at 10434. 


\section{EVOLUTION IN WATER LAW: ADAPTIVE WATERSHED GOVERNANCE}

Despite the maladaptive features of water law in the U.S., the system has adaptive features and capacity. One particularly promising adaptation to changing conditions and current systemic inadequacies is the emergence of watershed governance institutions, which in turn are adapting to opportunities, threats, disturbances, and changing conditions. ${ }^{195}$ This phenomenon is emerging from a mix of law-driven disturbances (e.g., the shadow of federal statutes and regulations, the effects or prospects of litigation), legal reforms (e.g., watershed planning statutes), self-organizing collaborative behaviors around watersheds, and community attempts to address specific water problems that are not addressed by existing legal frameworks. Law, society, and nature are not autonomous, self-contained systems, and the dynamic interaction of these systems stimulates adaptive, emergent phenomena such as watershed governance institutions. ${ }^{196}$

In California for example, the Santa Ana Watershed Project Authority's (SAWPA) 2010 Santa Ana Integrated Watershed Plan is an example of such adaptive watershed governance. ${ }^{197}$ First, the plan adopts a shared-risk strategy. It recognizes that climate change is occurring and that climate change is and will adversely impact the watershed as well as the region's water supply, economy, environmental health, and community vitality. ${ }^{198}$ It recognizes that there are a variety of quantitatively different climate change models that all simultaneously undermine the value of relying on past data, yet fail to provide a definitive prediction of future conditions. ${ }^{199}$ However, the plan evaluates its strategies for watershed management by applying a range of plausible models of future temperatures, precipitation, and sea level rise to address likely impacts in the watershed: increased evaporation and transpiration; increased water demands; longer, hotter, and more frequent heat waves; increased wildfire risks; higher peak energy demands; diminished air quality; changes in water temperatures; decreased water quality and related biotic stresses; decreased precipitation on supplies of imported

195. See id. at 10435; Arnold, supra note 104, at 841-56.

196. On the interaction of interconnected social and ecological systems (including the role of law), see Elinor Ostrom's institutional analysis and development (IAD) and social-ecological systems (SES) frameworks: OSTROM, supra note 151; Elinor Ostrom, A General Framework for Analyzing Sustainability of Social-Ecological Systems, 325 SCI. 419 (2009).

197. SANTA Ana WATERShed Project Authority, supra note 169, Executive Summary.

198. See id. at ch. 5.9.

199. Id. 
water; increased flood risks; decreased groundwater replenishment; and risks to the reliability of local water supplies. ${ }^{200}$ The plan considers climate change analyses in connection with other sources of uncertainty and change, including Colorado River drought conditions, San Joaquin Delta vulnerability, and population growth and development. ${ }^{201}$

Moreover, all stakeholders in the watershed are to share in the risks associated with changing climate, water supplies, water demands, and watershed conditions, through tools like water conservation measures, changes in land-use planning and regulation, conjunctive management of surface water and groundwater with increased storage of water in the basin for future needs, public education programs, greater use of rainfall as a basin-wide water source, and increased use of best management practices (BMPs) to control and reduce polluted stormwater runoff. ${ }^{202}$

Second, the plan adopts conditional and flexible standards for adaptive implementation of the plan, instead of rigid rules. A variety of specific implementation strategies are guided by several goals and strategies. The goals are:

Provide reliable water supply;

Preserve and enhance the environment;

Promote sustainable water solutions;

Ensure high quality water for all users;

Provide economically effective solutions;

Improve regional integration and coordination;

Manage rainfall as a resource;

Preserve open-space and recreational opportunities, and

Maintain quality of life. ${ }^{203}$

The strategies are:

Increase storage;

Reduce demand;

Desalinate groundwater;

Recycle water;

Consider stormwater as water supply;

Value water differently;

Maximize preservation and use of native plants;

Develop risk-based WQ improvements

200. Id.

201. Id. at ch. 1 .

202. Id. at ch. 5.9

203. Id. at ch. 6 tbl.6-1. 
Incorporate integrated water planning in General Plans

Manage public property for more than one use;

Create watershed governance; and

Implement watershed-wide education programs. ${ }^{204}$

Some specific action items-also context-specific, flexible, and adaptive-include developing additional storage for recycled water, developing new pathogen indicators and new residual chlorine standards, reconsidering whether flood risk management should continue to be based on 100-year flood probabilities created from historic data, and changing landscaping practices to increase pervious hard surfaces, pavers, bio-swales, new irrigation technology, and water-efficient gardens in comprehensive landscape planning and consumer packages. ${ }^{205}$

Third, as the above-listed goals and strategies indicate, the plan is an integrated plan for watershed governance. It is organized around and focuses on the Santa Ana River Watershed. It creates a poly-resilient vision of "a sustainable Watershed that is drought-proofed, salt-balanced, and supports economic and environmental viability." 206 It integrates different fields of law and governance, including water supply, water quality, surface water, groundwater, land-use planning and regulation, and energy, among others. The planning process integrated "the local agencies, organizations and other interested parties within the Santa Ana River Watershed."207 It coordinates and integrates the use of multiple methods and tools to address the many interdependent threats to the watershed's functions and resilience. SAWPA and the many stakeholders involved in the Santa Ana River planning effort have improved on the plan that they adopted in 2010. On February 4, 2014, SAWPA adopted the One Water, One Watershed Plan 2.0 (OWOW 2.0), which reiterates the foundational goals of the original plan but also strengthens the structures and processes for integrated and collaborative management, adds specific performance standards or targets to achieve by 2035, and develops monitoring, assessment, and plan revision processes, thus adding the feedback loops that make the planning and implementation processes adaptive. ${ }^{208}$

\footnotetext{
204. Id. at tbl.6-3.

205. Id. at ch. 5 .

206. Id. at ch. 1 .

207. Id.

208. Santa Ana Watershed Project Authority, One Water, One Watershed 2.0 Plan, Executive Summary 5-8 (2014), available at http://www.sawpa.org/owow-2-0-plan-2/.
} 
Another example is the Blackfoot Challenge, which is a multiparticipant collaboration to protect the Blackfoot River watershed in Montana. $^{209}$ The Blackfoot Challenge is a grassroots organization that consists of over 100 ranchers and farmers in the Blackfoot River watershed as well as twenty-seven federal and state agencies and nongovernmental organizations. The U.S. Fish and Wildlife Service and Trout Unlimited were instrumental in starting the Blackfoot Challenge with area ranchers and farmers to address watershed problems in ways

209. The Blackfoot Challenge case study is based on a synthesis of the following sources: Blackfoot Challenge, A Basin-Wide Restoration ACtion Plan fOR the Blackfoot WATERSHED (2005), available at https://archive.org/details/basinwiderestora2005blacrich; BlaCKFOOT COMMUNITY CONSERVATION AREA COUNCIL, BLACKFOOT COMMUNITY CONSERVATION AREA: MANAGEMENT PLAN FOR THE CORE (2007), available at https://www.google.com/url?q=https://dnrc.mt.gov/Forestry/Assistance/Stewardship/Documents/BC CAPlandraft.pdf\&sa=U\&ei=IIYWU_P7BtPokAe-7oDgBw\&ved=0CAUQFjAA\&client=internaluds-cse\&usg=AFQjCNGyQNTNuu-x698PIT_VsTXf3KwhNg; CAROLYN MEHL \& JONATHAN HAUfler, NATIVE TERRESTRIAL ECOSYSTEM DiVERSITY OF THE BlaCKFOOT WATERSHED (2010), available at http://www.emri.org/PDF\%20Docs/Adobe\%20files/MT_CIG\%20final\%20report.pdf;

COMmunity-BASEd Conservation: 2010 Annual Report, Blackfoot Challenge (2010), available at http://blackfootchallenge.org/Articles/wp-content/uploads/2010/04/2010-BlackfootChallenge-Annual-Report.pdf; OFFICE OF WATER, EPA, EPA-840-R-00-001, PROTECTING AND RESTORING AMERICA'S WATERSHEDS: STATUS, TRENDS, AND INITIATIVES IN WATERSHED Management 22 (2001); USDA Natural Res. Conservation Serv., Conservation PRACTICES BENEFIT WESTERN NATIVE TROUT (2011), available at www.nrcs.usda.gov/Internet/ FSE_DOCUMENTS/16/stelprdb1041602.pdf; JULIA M. WONDOLLECK \& STEVEN L. YAFFEE, MAKING COLlaboration WORK: LESSONS FROM INNOVATION IN NATURAL RESOURCE MANAgEment 97, 130, 163, 185, 188, 215 (2000); Ron Pierce et al., Response of Wild Trout to Stream Restoration over Two Decades in the Blackfoot River Basin, Montana, 142 TRANSACTIONS OF THE AM. FISHERIES SOC'Y 68 (2012); Edward P. Weber, Getting to Resilience in a ClimateProtected Community: Early Problem-Solving Choices, Ideas, and Governance Philosophy, in Collaborative Resilience: Moving Through Crisis to OpPortunity 177, 177-206 (Bruce Evan Goldstein ed., 2012); Chrissy Coughlin et al., A Systematic Assessment of Collaborative Resource Management Partnership, ch. 6 (Apr. 1999) (unpublished Master's Project, University of Michigan School of Natural Resources and the Environment), available at http://www.snre.umich. edu/ecomgt/pubs/crmp.htm; THE BLACKFOOT CHALLENGE, http://blackfootchallenge.org/Articles/ (last visited Apr. 13, 2014); The Blackfoot Challenge, U.S. FiSH \& WILDLIFE SERV., http://www.fws. gov/mountain-prairie/pfw/montana/mt6.htm (last visited Apr. 13, 2014); History and Evolution of the Blackfoot Challenge, U.S. FISH \& WILDLIFE SERVICE, http://www.fws.gov/mountain-prairie/ pfw/montana/mt5a.htm (last visited Apr. 13, 2014); Montana - Restoring Stream Flows in Key River Basins, TROUT UNLIMITED, http://old.tu.org/conservation/western-water-project/montana/mtrestoring-stream-flows-in-key-river-basins (last visited Apr. 13, 2014); Blackfoot River Basin Fisheries Restoration, WILD FISH HABITAT InITIATIVE, http://wildfish.montana.edu/cases/browse _details.asp?ProjectID=71 (last visited Apr. 13, 2014); The Blackfoot Challenge: Working with local ranchers to create a Drought Response Plan, ClimateChAngeMt.org, http://www.climate changemt.org/focus-crown-of-the-continent/success-stories-2/blackfoot-challenge-2/ (last visited Apr. 13, 2014); Jerri Kershner, Restoring Stream Flows and Habitat: Lessons from the Blackfoot River Watershed in Montana, Climate AdAPTATION KNOWLEDGE EXChANGE (July 25, 2011), http://www.cakex.org/case-studies/4014 (case study on a project of the Big Blackfoot Chapter of Trout Unlimited, Montana Fish, Wildlife, and Parks, and Montana Trout Unlimited. Product of EcoAdapt's State of Adaptation Program). 
that are more flexible and participatory than the implementation of rigid command-and-control regulatory regimes like the Endangered Species Act. While the organization is collaborative and voluntary, it has not shied away from adopting standards to improve the resilience of the watershed and its local community. It began by providing information, education, and technical assistance for noxious weed control, cattle BMPs for riparian protection, proactive bear interaction management, and proactive wolf interaction management. Eventually, it created and funded a land and conservation easement program that limited land development to protect the rural way of life in the Blackfoot Valley and the environmental quality of the watershed. More recently, the Blackfoot Challenge developed a Drought Response Plan for addressing the impacts of climate change, which calls for shared reductions in usage during times of drought regardless of the participants' prior appropriation rights. Despite the collaborative, voluntary nature of the Blackfoot Challenge, water quality and flows, aquatic species health, and wildlifehuman interaction patterns have improved in the watershed. This collaboration exemplifies the role of shared risk, conditional and flexible standards, and the integrated water governance that can arise in the shadow of less adaptive legal regimes, which can improve socialecological resilience and a community's adaptive capacity.

In another example, statutorily-mandated watershed planning has produced surprisingly resilient and adaptive watershed governance systems. Formal state-mandated watershed planning processes can produce unanticipated consequences as legal requirements intersect with multiple and evolving frames of watersheds. In 1998, the Washington Legislature enacted the Watershed Planning Act, which mandates watersupply planning for Watershed Resource Inventory Areas (WRIAs), which are state-designated hydro-geographic units. ${ }^{210}$ Multi-participant

210. The Washington Watershed Planning Act case study is based on a synthesis of the following sources: Watershed Planning Act, WASH. REV. CODE ANN. \$§ 90.82.005-90.82.902 (West 2013); City of Olympia, Washington, LOW-IMPaCt DeVelopMent STRATEgy For Green Cove Basin: A Case Study in Regulatory Protection of AQuatic Habitat in Urbanizing Watersheds (2002); Colville River Watershed Planning Team, WRIA 59 - Colville RiVer WATERSHed Plan Version 2.0 (2007); WRIA 34 - PALOUSE WATERSHEd Plan (2007); King CNTY., DeP'T OF NATURAl Res. \& LAND Res. Div., VASHON-MAURy ISLAND WATERShed Plan (2005); WA DEP'T OF ECOlOGY, No. 12-11-002, 2011 REPORT tO THE LEGISLATURE: Statewide Progress on Setting Instream Flows (2012); WA DeP't of ECOlogy, No. 08-01018, Working FOR Washington's Future: Healthy Watersheds, Healthy PeOPle (2008); Craig Anthony (Tony) Arnold, The Structure of the Land Use Regulatory System in the United States, 22 J. LAND USE \& ENVTL. L. 441, 469 n.135 (2007); Binder, supra note 49, at 924-25; Chris Pitre \& Lisa Daily Wilson, Watershed Planning in Washington State, LAND \& WATER, July/Aug. 
watershed planning groups are required to plan for future off-stream uses in relationship to minimum instream flows with a goal of obtaining maximum citizen input. Optional elements of the planning process include establishment of water-quality goals, habitat conditions, and minimum instream flows. Nonetheless, many watershed groups have engaged in integrated planning regarding these optional elements and have chosen to pursue shared-risk strategies. The content of watershed plans has varied considerably across WRIAs. Some WRIA planning units developed watershed-focused zoning and land-use regulations to protect waters from polluted runoff, which were adopted by local governments. Some engaged in planning for climate change. The planning processes created demand for data and scientific modeling of climate change impacts at local or watershed scales. Instead of adopting inflexible rules about future water conditions, they are seeking flexible standards based on watershed-function and climate-change indicators. Some planning groups had difficulty overcoming constraints on capacity (e.g., resources, expertise, trust), but most overcame these constraints and produced adaptive plans. Many watershed planning groups have continued to operate long after they adopted their plans, even though they are not legally required to do so. Furthermore, the Washington Department of Ecology uses watershed assessments developed by WRIAs in the watershed planning process to evaluate new water rights permit proposals.

The list of adaptive watershed governance systems includes Eastern watersheds. In the Green River of Kentucky, the U.S. Army Corps of Engineers and The Nature Conservancy have adaptively managed a federal dam and related water flows to control flooding and protect endangered mussels downstream. They have also created conservation easements to protect water quality and are starting an adaptive watershed planning process. ${ }^{211}$ The Anacostia River Watershed in Maryland and

2004, at 56; Clare M. Ryan \& Jacqueline S. Klug, Collaborative Watershed Planning in Washington State: Implementing the Watershed Planning Act, 48 J. EnvTl. Planning \& MGMT. 491 (2005); Amy K. Snover et al., Climate-Change Scenarios for Water Planning Studies: Pilot Applications in the Pacific Northwest, 84 Bull. Am. Meteoro. Soc. 1513 (2003); The Watershed Planning Act, WA DEP'T OF ECOLOGY, http://www.ecy.wa.gov/watershed/misc/background.html (last visited Apr. 13, 2014); Watershed Management, WA DEP'T OF ECOLOGY, http://www.ecy.wa.gov/watershed/ index.html (last visited Apr. 13, 2014).

211. The Green River case study is based on a synthesis of the following sources: SANDRA POSTEl \& BRIAN RichteR, RiVERS FOR LIFE: MANAGING WATER FOR PEOPLE AND NATURE 151-57 (2003); U.S. ARMY CORPS OF ENG'RS, LOUISVILle District, GREEN RiVER WATERSHED SECTION 729 InITIAL WATERSHED ASSESSMENT (2011); John Hickey \& Andy Warner, Green River Lake and Dam Interim Plan Benefits Ecosystems, THE CORPS ENVIRONMENT, Oct. 2006, at 11; John Hickey \& 
the District of Columbia has seen cooperation between urban and upstream suburban/rural communities to adaptively restore and protect the Anacostia in pursuit of co-benefits through integrated methods that extend beyond legal mandates:

- A multi-jurisdictional agreement among Maryland, the District of Columbia, Montgomery County (MD), and Prince George's County (MD) for watershed restoration and protection;

- The Eastern Montgomery County Master Plan with policies for headwater protections, down-zoning in trout-spawning areas, impervious cover limits, and land acquisition in stream valleys;

- A comprehensive plan for the Paint Branch watershed (a subwatershed);

- The designation of the upper Paint Branch area as a Special Protection Area in the County Code, with conservation buffers for streams, wetlands, springs, and floodplains, requirements of a water quality plan for all public and private projects in the area, and limits on impervious cover to ten percent of the surface area or any development site unless the developer uses off-site mitigation or obtains a waiver;

- The designation of an Environmental Overlay Zone that restricts certain land uses near the upper Pain Branch's headwaters;

- The conditioning of land-use and environmental permits on stormwater runoff minimization and mitigation, best management practices to avoid erosion or sediment runoff, dedication of open space and buffer areas, and limits on impervious cover;

- Park acquisition planning for government acquisition of identified riparian and sensitive headwater lands, and implementation of plans with significant acquisitions of carefully selected critical lands;

- Altering public land and facility operations that were polluting the Anacostia River, such as a bus depot leeching oil or the National Zoo dumping animal waste;

\footnotetext{
Andy Warner, River Project Brings Together Corps, The Nature Conservancy, THE CORPS EnVIRONMENT, Apr. 2005, at 10, 12; Chuck Mason, Officials: Green River a Resource that Needs Spotlight, Protection, Bowling GreEn DaILY News (Feb. 23, 2014), http://www.bgdailynews .com/news/officials-green-river-a-resource-that-needs-spotlight-protection/article_6a62d377-a66d5e02-8cba-c5c308d9ee33.html?mode=story; Kentucky: The Green River, THE NATURE CONSERVANCY, http://www.nature.org/ourinitiatives/regions/northamerica/unitedstates/kentucky/ placesweprotect/green-river.xml (last visited Apr. 13, 2014); Green River, GREAT RIVERS PARTNERSHIP, http://www.greatriverspartnership.org/en-us/NorthAmerica/Mississippi/Pages/Green River.aspx (last visited Apr. 13, 2014).
} 
- Upgrading wastewater and sewer facilities;

- Trash and litter cleanup projects;

- Restoration projects that have stabilized stream bank erosion, replaced artificial channels with natural streambed characteristics, restored degraded wetlands, returned native species to creeks, and planted trees and vegetation in riparian zones;

- The protection of watershed-serving features of privately owned lands with conservation easements on tens of thousands of acres;

- An environmental compliance outreach program for auto repair shops in the Hickey Run subwatershed;

- A project to involve local residents, including low-income inner city school children, in small-scale watershed restoration efforts, such as stream cleanup projects, planting native trees, stenciling storm drains, and offering public education about the watershed and its conditions;

- Extensive activities of the Anacostia Watershed Society, involving tens of thousands of volunteers in public engagement with and support for watershed protection through activities such as watershed stewardship photo essays, recreation-based education about the watershed, elementary school science programs based on student interaction with the river ecosystem, teacher training, newsletters, fish propagation projects, tree and native-plant planting projects, storm drain stenciling, non-native plant removal projects, river and trash cleanup, stream bank stabilization projects, and river tours. ${ }^{212}$

Watershed governance is not a panacea that will provide all the social-ecological resilience and adaptive capacity that water law needs. ${ }^{213}$ There are substantial barriers to watershed protection and governance for social-ecological resilience. ${ }^{214}$ Adaptive and collaborative planning and management at watershed scales might produce only psychologically and socially satisfying cooperation (e.g., the development of social capital) without substantial improvements in ecosystem health and function. ${ }^{215}$ Watershed governance might fail to develop fully adaptive structures and systems, including the use of feedback loops to evaluate the

212. Craig Anthony (Tony) Arnold, For the Sake of Water: Land Conservation and Watershed Protection, SuSTAIN, Spring/Summer 2006, at 16, 21-27.

213. Ruth Meinzen-Dick, Beyond Panaceas in Water Institutions, 104 PROC. NAT'L ACAD. SCI. 15200 (2007).

214. Adler, supra note 187; Cosens \& Williams, supra note 60.

215. See Judith A. Layzer, Natural Experiments: Ecosystem-Based Management AND THE ENVIRONMENT (2008). 
implementation of plans, programs, and legal reforms. ${ }^{216}$

Nonetheless, watershed-based governance institutions are increasing in number, roles, and impact in water resource management in the U.S. They offer important lessons for water law about adaptation to disturbances and changing conditions. Many watershed governance institutions use shared-risk strategies, conditional and flexible standards, and integrated water governance structures and processes. They are changing how water law functions in the U.S. and pointing the way to make water law more adaptive for social-ecological resilience.

216. See Lawrence Susskind et al., Collaborative Planning and Adaptive Management in Glen Canyon: A Cautionary Tale, 35 ColuM. J. ENVTL. L. 1 (2010). 